\title{
Fiscal sustainability and the cyclically adjusted balance policy: methodology and analysis for Chile
}

\author{
Mauricio G. Villena, Cristóbal Gamboni \\ and Andrés Tomaselli
}

\begin{abstract}
This paper sets forth a framework for analysing fiscal sustainability in the Chilean economy. It starts by making an ex post calculation of indicators of vulnerability and fiscal sustainability, based on the estimation of a sustainable debt level, with public finances considered in stationary state. It then develops an ad hoc dynamic fiscal sustainability model for Chile's public finances, which for the first time incorporates the dynamic of the Pension Reserve Fund (FRP) with its accumulation and disbursement rules, together with the cyclically adjusted balance policy. Lastly, the study simulates the path of the budgetary central government's net debt up to 2025, using the projections made in the 2018 Public Finance Report, under a macroeconomic trend scenario and another adverse scenario, all framed by the cyclically adjusted balance rule.
\end{abstract}

\section{Keywords}

Tax administration, fiscal policy, public finance, macroeconomics, public debt, economic indicators, economic trends, Chile

\section{JEL classification}

E62, H6, O23, O11

\section{Authors}

Mauricio G. Villena is a full professor in the Business School at Adolfo Ibáñez University, Santiago, Chile. Email: mauricio.villena@uai.cl.

Cristóbal Gamboni is Senior Economist at BBVA Research, Chile. Email: cristobal. gamboni@bbva.com.

Andrés Tomaselli is a student enrolled in the master's programme in public policy of the University of Chile. Email: aptomaselli@gmail.com. 


\section{Introduction}

High and rising debt levels undermine a country's credit rating, thereby generating greater uncertainty in financial markets and driving up the risk premium. This forces the country in question to spend more on debt service, thereby putting greater pressure on other expenditure. In many cases, the only way to reduce the deficit in the short term is by cutting back on public spending, which has negative social consequences.

The dynamics and sustainability of the public debt depend on the behaviour of the public deficit and its interrelationship with the different phases of the business cycle, its vulnerability or volatility in the face of exogenous shocks, capital markets, domestic and external interest rates, and the real exchange rate. A country's net public debt represents accumulated past fiscal outturns, while future balances incorporate the resulting interest income and expenses. Systematic fiscal imbalances will thus generate future interest expenditure, which in turn will contribute to the accumulation of new debt.

For nearly two decades, Chilean fiscal policy has been based on a cyclically adjusted balance (CAB) rule applicable to total central government, which is consistent with the medium-term macroeconomic equilibria -in other words with a level of public debt that is sustainable through time. ${ }^{1}$ In practice, this implied a decreasing trend in the accumulation of gross liabilities by the budgetary central government ${ }^{2}$ until 2010, which has tended to reverse more recently but without returning to the levels of pre-rule years. Figure 1.A shows that, on average, the gross debt/GDP ratio fell from $22.6 \%$ in $1990-2000$ to $11.1 \%$ in $2001-2016$.

Figure 1

Central government debt, 1990-2016

A. Central government financial assets and total gross financial liabilities, 1990-2016

(Percentages of GDP)

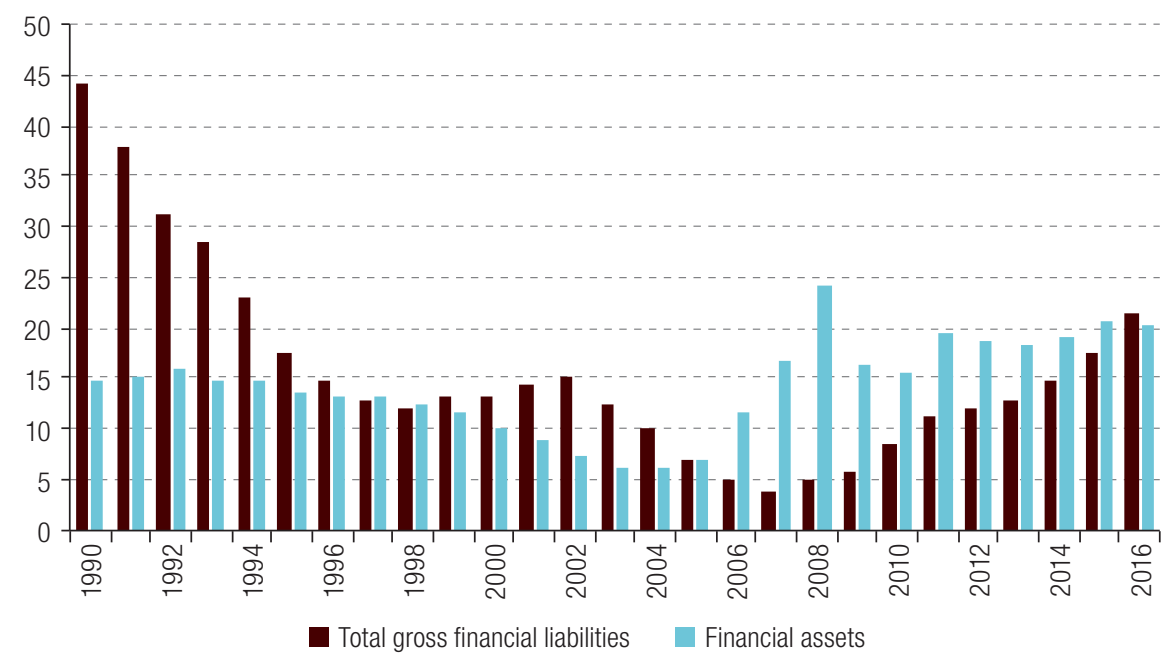

1 The total central government encompasses institutions that are subject to the same budgetary planning and execution rules, which are closely related to the Executive Branch, plus the extra-budgetary operations associated with this level of government.

2 Although this paper considers income and expenditure flows for total central government, it analyses both gross and net debt stocks for the budgetary central government. The perimeter of the latter excludes unpaid recognition bonds for reasons explained below. 
Figure 1 (concluded)

B. Central government net financial liabilities, 1990-2016

(Percentages of GDP)

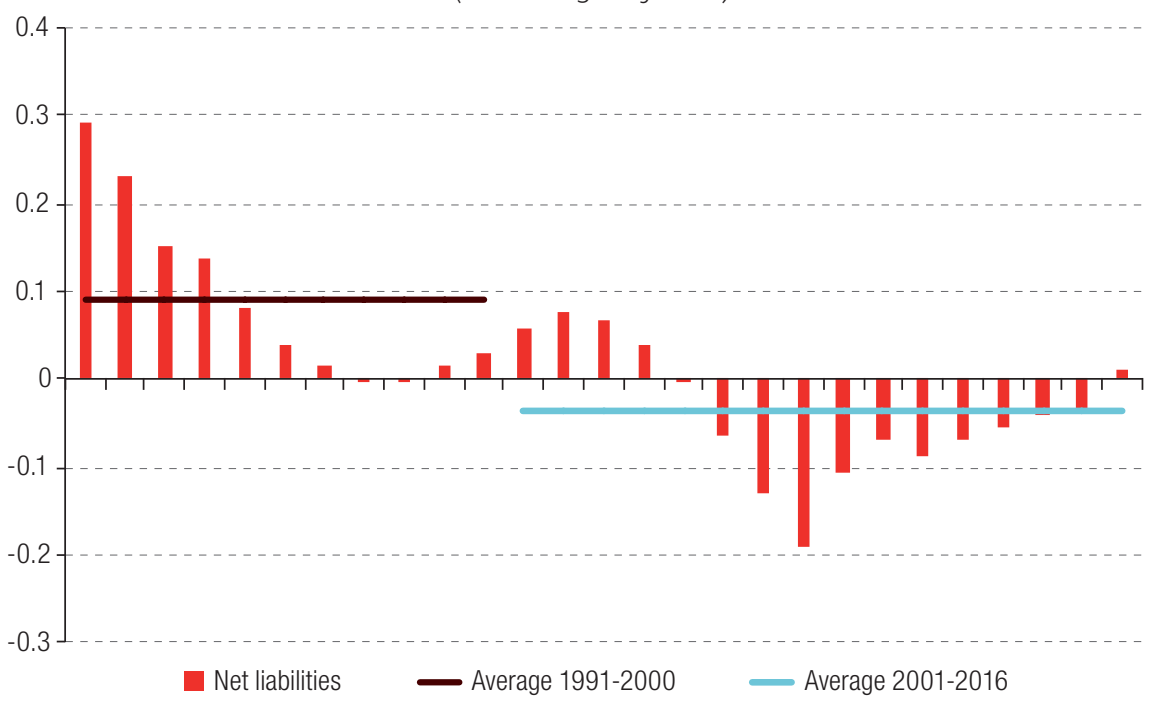

Source: Prepared by the authors, on the basis of information from the Ministry of Finance and the Central Bank of Chile.

Thus, while the CAB rule has been in force, the budgetary central government moved from a net debtor position in 2000 to become a net creditor in 2005; and it maintained that status until 2015 (see figure 1.B). This trend of net borrowing has enabled Chile to improve its credibility as a debt issuer, both domestically and internationally.

Despite these fiscal-policy achievements, Chile's fiscal accounts have come under heavy pressure in the last decade - first and foremost because of the international financial crisis of 2008-2009 and the February 2010 earthquake and tsunami. In recent years, however, fiscal policy has also been exposed to a number of imbalances that have resulted in five consecutive years of budget deficits, with a consequent increase in debt. The sustained deterioration of the fiscal situation meant that, after 12 years as a creditor, Chile became a net debtor again in 2016, with a net debt of $1 \%$ of GDP. This fiscal position takes the country back to 2004, when its net debt represented 4\% of GDP; and it is consistent with the growth of gross debt, which reached $21.3 \%$ of GDP in 2016, its highest level since the $22.9 \%$ attained in 1994 (see table 1). As a result of the increase in net debt, interest expenses are now over US\$ 1 billion greater than in 2009 (DIPRES, 2017d). ${ }^{3}$ This fiscal deterioration has been internalized by the risk rating agencies, with Standard \& Poor's downgrading Chile's long-term foreign currency risk rating for the first time in 25 years, from the AA- gained in 2012 to A+ (see Arellano, 2017, p. 14).

Although the current levels of Chile's central government net debt do not seem unduly high compared to those of other countries in the region or in the Organization for Economic Cooperation and Development (OECD), the spending pressures projected for the coming years could render its fiscal position increasingly vulnerable. A question that arises in this scenario is the extent to which Chile's long-term fiscal sustainability is compromised in the event of potential turbulence in the economy.

This article contributes to discussion on this issue by proposing a framework for analysing fiscal sustainability in the Chilean economy. To that end, it starts by making an ex post calculation of vulnerability and fiscal sustainability indicators adapted to the Chilean fiscal reality, based on an estimated sustainable debt level, considering public finances in stationary state. This makes it possible to quantify the evolution of Chilean fiscal sustainability and shed light on the impact of recent crises.

3 See DIPRES (2017d). 
Secondly, as the indicator analysis is static and does not make it possible to simulate the potential effects of an economic crisis on Chile's public finances, this study develops a dynamic model of fiscal sustainability. Its specific contribution to the literature is to develop an ad hoc model for Chilean public finances, which for the first time incorporates the dynamics of the Pension Reserve Fund (FRP) set up in 2006, with its accumulation and disbursement rules, together with the structural-balance policy currently in force (Larraín and others, 2011; DIPRES, 2017a).

Lastly, to exemplify the functioning of the proposed dynamic model, the study simulates the path of the net debt of Chile's budgetary central government up to 2025, evaluating both a macroeconomic trend scenario and an adverse one, all framed by the CAB rule. The trend scenario considers the initial position of the 2018 budget and the public-sector financial projection for 2019-2021 (see DIPRES (2017b)), with convergence to its trend values. In the adverse scenario, the public-sector financial projection is also considered as a basis, but an external demand crisis is simulated from 2018 onward, which seriously undermines GDP growth in the ensuing years. Following the activity slowdown, a steady recovery period is envisaged, culminating in convergence to the trend values by the end of the projection period.

This article is organized as follows; section II makes a brief review of the economic literature on fiscal sustainability models; and section III reviews the cyclically adjusted balance indicator, which is the cornerstone of Chilean fiscal policy and, hence, the basis of the fiscal sustainability evaluation. The first part of section IV discusses selected indices of vulnerability and fiscal sustainability for 1990-2016, while the second applies the proposed dynamic model. Lastly, section $V$ sets forth final comments and recommendations.

\section{Literature review}

Fiscal sustainability models can be divided into three broad categories. The first consists of long-term models, based on the calculation of a sustainable level of debt with stationary-state public finances and future information without uncertainty. The category includes the indicators proposed by Blanchard (1990) and Buiter (1985). The second set of models recognizes the intertemporal changes to which government budget constraints are susceptible, for which they explore the time-series properties of fiscal balance and whether they satisfy the conditions for keeping public finances on a sustainable path (non-Ponzi condition). Models of this type include those developed by Hamilton and Flavin (1986), Chalk and Hemming (2000) and Bohn (1998 and 2005). The latter model, which is also used by the International Monetary Fund (IMF, 2003), regresses the primary balance against net debt, to search for evidence that the debt/GDP ratio is subject to mean reversion. The third and last category introduces uncertainty into variables on the income side (especially for economies that depend on commodity sales) and in the financial market. Studies that have explored this type of model include Calvo, Izquierdo and Talvi (2003), which evaluates changes in relative prices for the Argentine economy; Barnhill and Kopits (2003), which incorporates uncertainty with the value-at-risk (VaR) methodology; and Mendoza and Oviedo (2006), which develops a dynamic stochastic general equilibrium (DSGR) model to calculate the natural debt limit for Mexico. Mendoza and Oviedo (2009) present a cut-down version of this model, which incorporates tax-revenue uncertainty and calculates the natural debt limit for four Latin American countries.

This third group also includes the IMF model for developing countries (IMF, 2002, 2003 and 2010), which makes assumptions about short-term variables to be able to gauge their impact on fiscal sustainability. In terms of formal empirical measurements that specifically analyse the Chilean case, there are at least two studies that follow an approach similar to the IMF model. Vergara (2002) estimates the primary balance that is consistent with a net-public-debt-to-GDP ratio of $20 \%$ for different growth rates and long-term real interest rates; and Crispi and Vega (2003) dynamically assesses the 
sustainability of Chile's fiscal policy, using a methodology for projecting central government net debt and analysing the effect of applying the CAB rule on the path of the net-debt-to-GDP ratio under three alternative scenarios: a base scenario, a cyclical base scenario and a historical scenario. The current study is aligned with this type of analysis and contributes to the literature by developing a dynamic sustainability model, updated according to the main fiscal-policy guidelines currently prevailing in Chile. The study innovates by being one of the first to incorporate the dynamics of FRP, which can legally be considered as an important debt component until 2016, since it only had an accumulation rule until that year. In addition, the CAB rule is modelled using its latest methodological update (DIPRES, 2017a).

\section{The cyclically adjusted balance rule}

Since 2001, Chilean fiscal policy has been guided by a CAB rule, known in the literature as the total central government structural balance. The policy has a medium-term perspective, unlike the traditional analysis based mainly on the actual balance, which represents a specific conjuncture.

The CAB policy broadly consists in estimating central government revenues adjusted for the business cycle, and authorizing public expenditure consistent with those revenues. This seeks to overcoming the traditionally procyclical behaviour of fiscal policy. ${ }^{4}$ The policy entails accumulating savings when economic activity is booming, and incomes are higher owing to the phase of the cycle, to be spent either when the economy contracts and tax revenues fall, or when situations that require additional expenditure arise.

Application of the CAB rule and its institutional framework have been considered successful and crucial to Chile's strong fiscal performance, attracting cross-cutting support from broad sectors of society. It has also become an international benchmark for fiscal responsibility. ${ }^{5}$ The International Monetary Fund (Dabán, 2011) considers the rule to be the "cornerstone of Chile's impressive fiscal performance".

The benefits of Chile's CAB policy include the fact that it has made a key contribution to: reducing fiscal and macroeconomic volatility, increasing public saving during business-cycle upswings, reducing risk perceptions of the Chilean economy, reducing interest-rate volatility and helping to sustain a more competitive and less volatile real exchange rate. This has made it possible to underpin the competitiveness of the export sector, despite a pronounced upward trend in the price of copper at the start of this decade. ${ }^{6}$

In its nearly 20 years of implementation, the CAB policy has undergone revisions and changes in its institutional framework, in its policy target, and in the concept and method of measuring the cycle.

The current policy is based on three pillars (Larraín and others, 2011):?

(1) A CAB indicator, consisting of the set of equations and variables needed to calculate a balance, with business-cycle effects stripped out.

(2) A policy target, defined independently of the measurement of the CAB indicator, which establishes the net liabilities accumulation path, free from business-cycle effects.

(3) An institutional and transparency framework which supports the proper functioning of the rule.

\footnotetext{
4 See Gavin and others (1996), Alberola and Montero (2007) and Ilzetzki and Végh (2008).

5 For more details see IDB (2008), IMF (2010) and OECD (2010). See also Frankel (2011).

6 See, for example, Costa and Lagos (2001), Larraín and Parro (2006), Le Fort (2006), Rodríguez, Tokman and Vega (2006), Kumhof and Laxton (2009), Ffrench-Davis (2010), Chan-Lau and others (2010), Marcel (2010), OECD (2010), Schmidt-Hebbel (2010), Ter-Minassian (2010), Velasco and others (2010), Frankel (2011), Tapia (2015) and Caputo and Valdés (2016).

7 See also Corbo and others (2011).
} 
From these three elements, only the characteristics of the CAB indicator are now reviewed for subsequent incorporation into the sustainability model.

Basically, the $\mathrm{CAB}$ indicator consists in defining a level of expenditure consistent with an income level purged of cyclical fluctuations in GDP and copper prices, over which the authority has no direct control. The underlying aim is to obtain a balance that allows automatic stabilizers to operate to the full. Any other type of fluctuation in income is not adjusted, so as to avoid different interpretations of what is permanent or transitory and what is not, and to prevent discretionary actions by the authority.

In practice, this means not correcting income for transitory tax measures or operations that change income on a once-only basis. On the other hand, tax measures that automatically reverse themselves are corrected for -these being understood as measures that have cash flow effects on tax revenues, in other words those that merely involve advances or delays in tax payments. Variations associated with events unrelated to the cycle are not adjusted for and, as such, could generate certain levels of volatility in cyclically-adjusted revenues (for example, variations in inflation or exchange rates).

The institutional coverage of the indicator corresponds to the global balance of total central government, since this is the aggregate on which fiscal policy is formulated and executed. Although public enterprises, municipalities and State universities fall outside this perimeter, much of the fiscal policy influence exerted through these institutions involves transfers either from them or to them, which are recognized in the central government budget.

To estimate the structural balance, the sum of the cyclical adjustments of the different income items is subtracted from total measured or actual income, using the following formula:

$$
\begin{gathered}
B C A_{t}=B E f_{t}-A C_{t} \\
A C_{t}=I T N M_{t}^{c}+I C S_{t}^{c}+I T M_{t}^{c}+I C C_{t}^{c}
\end{gathered}
$$

where $B C A_{t}$ corresponds to the cyclically adjusted balance (CAB) in period $t$; BEft represents the actual balance reported in period $t$; and $A C_{t}$ denotes the cyclical adjustment to income in period $t$, which corresponds to the sum of the cyclical components expressed by the superscript $c$ of the following items: (1) non-mining taxes (ITNM), (2) social-security contributions (ICS), (3) taxation of large-scale private-sector mining (ITM); and (4) CODELCO transfers in respect of copper (ICC).

The non-mining tax revenue item, along with the adjustment for social security contributions, is obtained with the standard methodology used by international organizations, which consists of multiplying actual income by the output gap with an elasticity exponent. ${ }^{8}$ Moreover, the adjustment for taxation of large-scale private-sector mining and the CODELCO transfers takes account of the difference between the reference price of copper and its current price.

No cyclical adjustments are made for interest on financial assets or liabilities; and other tax revenues are also not adjusted because they are only weakly related to the output cycle. Moreover, as there are no expenditure components that respond automatically to the business cycle, spending does not need adjustment. A detailed review of the methodology for calculating the CAB indicator can be found in DIPRES (2017a).

\footnotetext{
8 See Giorno and others (1995), Hagemann (1999) and Larch and Turrini (2009).
} 


\section{Fiscal sustainability of the Chilean economy}

\section{Static indicators of vulnerability and fiscal sustainability}

The following paragraphs discuss the ex post calculation of selected indicators of vulnerability and fiscal sustainability adapted to the Chilean reality. ${ }^{9}$

The debt measurement presented below covers the budgetary central government, ${ }^{10}$ thereby excluding from the analysis the assets and liabilities of the Central Bank of Chile, public enterprises, universities and municipalities. The measurement of the gross liabilities of the budgetary central government also excludes the stock of unpaid recognition bonds, which represent a liability owed to affiliates of the old pension regime who transferred to the pension fund management (AFP) system. As the stock of recognition bonds is judged to be a different type of liability than the traditional concept of central government debt, and in keeping with international practices, these statistics are presented in a complementary manner and tend not to be consolidated into central government debt statistics.

Figure 2 depicts the evolution of central government finances as a percentage of GDP from 1990 to 2016, which initially give rise to the government's debt situation and thus directly impact fiscal sustainability levels. Prior to the application of CAB, the global balance was already in surplus. The deficit years are generally associated with turbulence in the economy, particularly 2009, which reports the largest deficit of the entire period analysed (which included the international financial crisis and the fiscal stimulus plan). The deficit has also been trending upwards, marginally since 2013 , at a rate of $0.6 \%$, but much faster in the last three years, by an average of $2.1 \%$.

Figure 2

Central government income, expenditure and balance, 1990-2016

(Percentages of GDP)

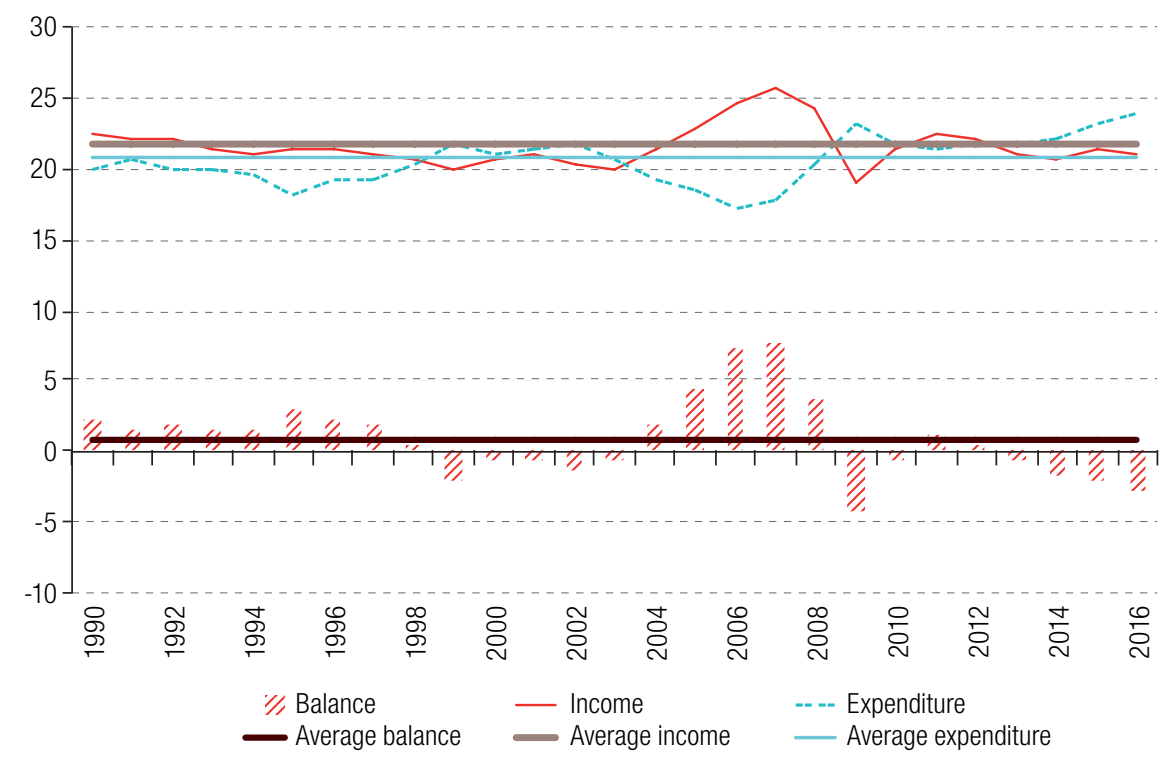

Source: Prepared by the authors, on the basis of information from the Budgetary Affairs Bureau (DIPRES).

9 The formula for calculating these indicators is presented in annex A1.

${ }^{10}$ For an analysis that considers the central government together with public enterprises and the central bank, see Vergara (2002). 
Table 1, below, reports the behaviour of the fiscal sustainability indicators, together with the impact on Chile's fiscal position and debt sustainability caused by the 2008-2009 international financial crisis and the February 2010 earthquake and tsunami. The last row of the table shows the critical value or desirable range of each indicator, as a benchmark for comparison with each of the values recorded annually. Various criteria were used to obtain these values or ranges. The reference values published by the IMF were used when available; otherwise the value obtained from the definition of the indicator itself was assigned as a critical value.

Table 1

Chile: static indicators of vulnerability and fiscal sustainability, 1990-2016a (Percentages)

\begin{tabular}{|c|c|c|c|c|c|c|c|}
\hline Year & Gross debt/GDP & $\begin{array}{l}\text { Net debt/ } \\
\text { GDP }\end{array}$ & Debt service & $\begin{array}{l}\text { (IV) Debt } \\
\text { service } \\
\text { acid test }\end{array}$ & $\begin{array}{l}\text { ( }) \text { Primary } \\
\text { balance (IMF } \\
\text { methodology) }\end{array}$ & $\begin{array}{c}\text { (VI) Primary } \\
\text { balance (DIPRES } \\
\text { methodology) }\end{array}$ & $\begin{array}{l}\text { (VII) Structural } \\
\text { primary } \\
\text { balance }\end{array}$ \\
\hline 1990 & 44.0 & 29.4 & 23.5 & 29.7 & 5.4 & 5.4 & \\
\hline 1991 & 38.0 & 22.9 & 24.9 & 27.9 & 4.5 & 4.6 & \\
\hline 1992 & 31.2 & 15.1 & 19.5 & 21.4 & 4.4 & 4.5 & \\
\hline 1993 & 28.6 & 13.6 & 20.7 & 21.6 & 3.5 & 3.6 & \\
\hline 1994 & 23.0 & 8.2 & 15.6 & 16.8 & 3.4 & 3.4 & \\
\hline 1995 & 17.5 & 4.0 & 21.6 & 24.6 & 4.6 & 4.7 & \\
\hline 1996 & 14.8 & 1.5 & 16.7 & 18.1 & 3.5 & 3.5 & \\
\hline 1997 & 12.9 & -0.4 & 11.8 & 12.9 & 3.2 & 3.2 & \\
\hline 1998 & 12.2 & -0.3 & 12.8 & 13.2 & 1.6 & 1.6 & \\
\hline 1999 & 13.3 & 1.6 & 12.0 & 12.3 & -0.8 & -0.9 & \\
\hline 2000 & 13.3 & 3.1 & 8.5 & 9.0 & 0.5 & 0.5 & \\
\hline 2001 & 14.4 & 5.6 & 10.0 & 10.4 & 0.6 & 0.6 & 2.3 \\
\hline 2002 & 15.2 & 7.7 & 13.6 & 14.0 & -0.1 & -0.1 & 1.9 \\
\hline 2003 & 12.6 & 6.5 & 12.2 & 12.8 & 0.7 & 0.6 & 1.9 \\
\hline 2004 & 10.3 & 4.0 & 13.5 & 16.2 & 3.0 & 2.9 & 2.0 \\
\hline 2005 & 7.0 & -0.1 & 15.2 & 19.4 & 5.2 & 5.0 & 1.8 \\
\hline 2006 & 5.0 & -6.6 & 8.0 & 12.3 & 8.0 & 7.7 & 1.8 \\
\hline 2007 & 3.9 & -13.0 & 6.7 & 9.9 & 8.3 & 7.8 & 1.1 \\
\hline 2008 & 4.9 & -19.3 & 6.3 & 8.2 & 4.4 & 3.7 & 2.9 \\
\hline 2009 & 5.8 & -10.5 & 6.3 & 7.3 & -3.8 & -4.3 & -2.9 \\
\hline 2010 & 8.6 & -7.0 & 4.1 & 5.2 & 0.0 & -0.2 & -1.5 \\
\hline 2011 & 11.1 & -8.6 & 4.7 & 5.7 & 1.8 & 1.5 & -0.5 \\
\hline 2012 & 11.9 & -6.8 & 6.2 & 7.2 & 1.1 & 0.8 & -0.6 \\
\hline 2013 & 12.7 & -5.6 & 6.9 & 7.7 & 0.0 & -0.3 & -1.3 \\
\hline 2014 & 14.9 & -4.3 & 8.0 & 8.8 & -1.0 & -1.2 & -1.5 \\
\hline 2015 & 17.4 & -3.5 & 8.6 & 9.1 & -1.5 & -1.7 & -1.0 \\
\hline 2016 & 21.3 & 1.0 & 42.3 & 43.0 & -2.0 & -2.3 & -1.0 \\
\hline AVERAGE & 15.8 & 1.4 & 13.3 & 15.0 & 2.2 & 2.0 & 0.3 \\
\hline $\begin{array}{l}\text { Critical value or } \\
\text { desirable range }\end{array}$ & 25-30 (IMF) & $42.8^{b}$ & 25-35 (IMF) & 25-35 (IMF) & Value $=0$ & Value $=0^{c}$ & Value $=0$ \\
\hline
\end{tabular}

Source: Prepared by the authors, on the basis of information from the Budgetary Affairs Bureau (DIPRES) and the Central Bank of Chile.

a When measuring the indicators, the interest rate has been calculated as the implicit nominal rate on both loans and deposits.

b Average of OECD countries (1993-2010), general government.

c As this is a sustainable indicator, its average during the period constitutes a reference value for each year.

The figures show gross debt trending down from 1990 until the financial crisis of 2009, when the trend reverses, after which net debt as a percentage of GDP rises again every year. These results are reflected in the behaviour of net debt as a percentage of GDP, which is calculated by subtracting 
central government assets (Economic and Social Stabilization Fund, Pension Reserve Fund and others) from the gross debt. The latter declines steeply from 1997 to 2008, owing both to reductions in gross debt and to asset growth, largely reflecting the significant cyclical component of revenues from copper, the price of which surged towards the middle of the decade of 2000 and thus allowed for a large increase in savings pursuant to the fiscal rule. In 2009, in the framework of the countercyclical policy partly financed with FEES funds, the trend reversed although it stayed negative. Under the current administration, the fiscal deterioration has continued, and in 2016 Chile ceased to be a net creditor for the first time in a decade.

In keeping with the above, debt service also decreased substantially. In simple average terms, prior to the operation of the CAB rule, these expenses absorbed about $18 \%$ of central government current income, or up to 20\% if copper revenues are excluded. Between 2000 and 2015, debt service fell to a simple average of $9 \%$ of current income, or $10 \%$ excluding copper. In 2016 , however, there was an abrupt increase in debt service which absorbed about half of central government current income, mainly owing to the repayments made in that year.

The declining debt trend meant that the primary balance, which excludes interest expenses under the IMF methodology, tended to converge with the global balance, as interest decreased as a proportion of total expenditure. Prior to 2014, the primary balance posted deficits in just three years, all of them associated with external financial crises. Since that year, greater spending pressures have generated two deficits in three consecutive years, which is unprecedented in the fiscal accounts of the last two decades. A similar pattern can be seen if the primary balance is calculated according to the methodology of the Budget Affairs Bureau (DIPRES), which also excludes income obtained from interest on central government financial assets.

When income is corrected for the business cycle, the primary CAB remains positive and relatively stable until 2008, with a structural balance target of 1\% of GDP until 2007 and one of $0.5 \%$ in 2008. Then, the fiscal package that was implemented in 2009 resulted in a cyclically adjusted deficit of $3.1 \%$ of GDP, and the primary CAB turned negative. Since that year and with a convergence target in place, this indicator has displayed negative values.

In short, the indicators improved during the first few years in which the fiscal rule was in place, when it targeted a structural surplus of $1 \%$ of GDP. Since 2009 with the international financial crisis, 2010 with the earthquake and tsunami, and 2011 with growing fiscal expenditure pressures, the figures have tended to deteriorate, although they remain stronger than in the early 1990s.

\section{The dynamics of fiscal policy and its sustainability within the framework of the cyclically adjusted balance policy}

This section analyses the dynamics of fiscal sustainability under the fiscal rule applied in Chile.

\section{(a) Methodological background}

Projecting future balances and, hence, future debt, is a key part of studying public-finance sustainability. As noted in several countries, fiscal imbalances can lead to severe crises, with effects lasting many years. This makes it necessary to analyse both the stock of debt held by a country and the flow generated each year. In this case, the flow is determined by deficits or surpluses recorded year by year in the government's fiscal accounts. 
The next section describes a model that analyses the path of the debt, considering both stocks and flows and emphasizing ex post variables. ${ }^{11}$

\section{(i) Economics of sustainability models}

The fiscal sustainability literature is based on the following equation, which describes the intertemporal relationship between the debt and the government's operating deficit in nominal terms:

$$
D_{t}=\left(1+i_{t}\right) D_{t-1}-B P_{t}-\Delta M_{t}
$$

where $D_{t}$ denotes the cumulative debt stock at the end of period $t, i_{t}$ is the nominal interest rate, $\Delta M_{t}$ is the growth of the monetary base at the end of period $t$ (seigniorage) and $B P_{t}$ is the primary balance ${ }^{12}$ in period $t$. To reflect the change in the debt in a given year, $D_{t-1}$ is subtracted from both sides of the equation, to obtain:

$$
\begin{gathered}
D_{t}-D_{t-1}=\left(1+i_{t}\right) D_{t-1}-B P_{t}-\Delta M_{t}-D_{t-1} \\
\Delta D_{t}=i_{t} D_{t-1}-B P_{t}-\Delta M_{t}
\end{gathered}
$$

Lastly, to express the change in debt as a percentage of GDP, the equation is written as follows:

$$
\Delta d_{t}=\frac{r_{t}-g_{t}}{1+g_{t}} d_{t-1}-b p_{t}-\Delta m_{t}
$$

Where lowercase indicates variables expressed as a percentage of GDP, $r_{t}$ is the real interest rate in period $t$, and $g_{t}$ is the real growth rate of output in period $t$. Writing this equation as a function of the observed balance gives:

$$
\Delta d_{t}=\frac{1+i_{t}}{1+\gamma_{t}} \gamma_{t} d_{t-1}-\Delta m_{t}-b e f_{t}
$$

where $i_{t}$ and $\pi_{t}$ are the nominal interest rate and inflation in period $t$, respectively, and $\gamma_{t}$ is equal to the sum of $\pi_{t}+g \mathrm{t}+\pi_{t} g_{t}$.

In the Chilean case there are three other characteristics to be considered when analysing fiscal sustainability: (1) the cyclically adjusted balance rule; (2) the importance of copper revenues; and (3) the country's sovereign funds policy. The next section analyses these items and how they are taken into account in the fiscal sustainability calculation.

\section{(ii) Characteristics of the Chilean economy}

Under the Chilean fiscal rule, government spending is set according to the CAB target, defined as a percentage of each year's GDP. This means that the primary balance outturn will be determined fundamentally by the cyclical adjustment and the CAB target for the year.

As noted in equation (1), the CAB is equal to the actual balance minus the cyclical adjustment of revenues. This makes it possible to define the following:

\footnotetext{
11 This simulates the macroeconomic variables that determine Treasury revenue and expenditure and then analyses debt movement through time. An ex-ante analysis would be more rigorous, but much less simple: the variables that are considered here are usually endogenous and uncertain, in other words they are determined by their joint movement and do not have a clear future path. A documented example is the influence of public spending on the exchange rate (Arellano and Larraín, 1996). Despite this simplification, the ex post algebra of sustainability models remains a powerful tool for identifying possible future risks (Law, 2010).

12 Although only interest expenses are subtracted in this section, the DIPRES definition of the primary balance is implicitly being used, since interest is calculated on the net debt. Thus, as noted below, interest may be negative, if interest income exceeds the interest payable on the accumulated gross debt.
} 


$$
\begin{gathered}
B C A_{t}=B E f_{t}-A C_{t} \\
B E f_{t}=I T_{t}-G T_{t} \\
B C A_{t}=\left(I T_{t}-G T_{t}\right)-A C_{t} \\
B C A_{t}=\left(I T_{t}-G T_{t}\right)-\left(I T_{t}-I T_{t}^{*}\right) \\
B C A_{t}=I T_{t}^{*}-G T_{t}
\end{gathered}
$$

Where $B C A_{t}$ represents the cyclically adjusted balance; $B E f_{t}$ is the observed balance; $A C_{t}$ is the cyclical adjustment of income; $I T_{t}$ is total reported income; $G T_{t}$ is total government expenditure and $I T_{t}^{*}$ denotes cyclically adjusted income.

The cyclical adjustment of income will be simplified in this model and defined as follows:

$$
\begin{gathered}
A C_{t}={I T N M_{t, i}}\left(1-\left(\frac{Y_{t}^{*}}{Y_{t}}\right)^{\eta}\right)+\left(V C_{t} \cdot\left(P_{t}^{C}-P_{t}^{*}\right)+\right) \cdot e_{t} \cdot 2.204,62 \\
+\left(P_{t}^{B M L}-P_{t}^{*}\right) \cdot \tilde{\tau}_{t} \cdot Q_{t} \cdot e_{t} \cdot 2.204,62
\end{gathered}
$$

In this case, all non-mining tax revenues (along with health insurance contributions) are grouped under the $I T N M_{t}$ term, and an average aggregate elasticity $\eta$ is used. $Y^{*}$ represents trend output.

The formula used in this model to cyclically adjust CODELCO revenues is identical to that described in DIPRES (2017a), where $P_{t}^{C}$ and $P_{t}^{*}$ are the actual and reference copper prices, respectively, $V F$ is the physical production (sale) ${ }^{13}$ of copper and et denotes the nominal exchange rate of the period.

The cyclical adjustment made to the taxation of large-scale private mining firms is also simplified. Instead of separately adjusting the three types of taxes that these companies pay, an average rate $\tau_{t}$ is used to represent the tax burden borne by the mining companies on their production $Q$ in year $t$. That average rate is calculated by weighting the rates of each type of tax, namely the excise duty, and first category and additional income tax. In addition to taking into account the effect of remittances on the additional tax, this rate must consider the changes in the specific tax on mining activity. ${ }^{14}$

Lastly, it should be recalled that the Chilean fiscal rule fixes government spending in line with cyclically adjusted revenues and the CAB target. So, if the structural result is set by target, expenditure is determined as follows:

$$
G T_{t}=I T_{t}^{*}-\overline{B C A_{t}}
$$

In conjunction with the above, a large portion of total central government income is sourced from copper sales. Nonetheless, the price of copper has followed a pronounced cycle throughout history; and this has been reflected in fluctuating amounts of revenue collected by the government (Borensztein and others, 2010). So, both the income transferred from CODELCO and the tax revenue collected from the large-scale private mining firms are treated in the model as a component that is distinct from other government income and then adjusted according to the copper-price cycle. ${ }^{15}$

For purposes of the model, income and expenses will be disaggregated as follows:

$$
\begin{gathered}
I T_{t}=I T N M_{t}+I T M_{t}+\text { Codelco }_{t}+i_{t}^{R} \cdot \text { FRP }_{t-1}+\text { resto }_{t} \\
G T_{t}=\text { GOtros }_{t}+i_{t} \cdot D_{t-1}+\text { GPrev }_{t}
\end{gathered}
$$

\footnotetext{
${ }^{13}$ Quantity produced is considered the best indicator for projecting sales.

${ }^{14}$ Although income tax and excise duty are paid for production and sales at $t-1$, making $\tau$ depend on Qt- 1 would not allow for the additional tax to be taken into account. However, making everything depend on $t$ does make it possible to capture the effect of income and excise taxes, through the monthly advance payments they make during the year.

15 This natural resource is not expected to run out for many decades. See Borensztein and others (2010).
} 
Where $I T N M_{t}$ are non-mining tax revenues and health contributions in period $t ; I T M_{t}$ denotes revenue from mining taxes; Codelco represents income transferred from CODELCO and $i^{R} F R P_{t-1}$ is FRP interest income; all income sources that are not a function of the macroeconomic variables specified in this model are assumed exogenous and are encompassed in the variable resto.

The term $i_{t} D_{t-1}$ denotes interest payments on the net debt ${ }^{16}$ in period $t$; GPrev ${ }_{t}$ represents pension expenditure, which is exogenous and depends on demographic factors; and GOtros is other expenditure. The latter serves as the adjustment variable to ensure that total expenditure is equal to the cyclically adjusted revenues minus the structural balance target.

Government revenues are a function of macro variables as follows: ${ }^{17}$

$$
\begin{gathered}
\operatorname{ITNM}_{t}=\operatorname{ITNM}_{t-1} \cdot\left(1+\frac{\Delta P}{P_{t-1}}\right)\left(\frac{\Delta Y}{Y_{t}}\right)^{n} \\
I T M_{t}=\tilde{\tau}_{t} \cdot M g_{t}^{P} \cdot Q_{t} \cdot e_{t} \cdot 2.204,62 \\
\text { Codelco }=\left(M g_{t}^{C} \cdot V F_{t}\right) \cdot e_{t} \cdot 2.204,62 \\
M g_{t}^{P}=P_{t}^{B M L}-c_{t}^{P} \\
M g_{t}^{C}=P_{t}^{C}-c_{t}^{C}
\end{gathered}
$$

Where $c^{P}$ and $c^{C}$ are the unit costs of the large-scale private-sector mining firms and CODELCO, respectively.

Lastly, the Fiscal Responsibility Law (Law 20.128) was passed in September 2006, establishing, among other things, the requirement to save assets in the Pension Reserve Fund (FRP) and the Economic and Social Stabilization Fund (FEES). As of 31 August 2017, the funds in question, which have their own objectives and accumulation rules, had grown to US\$10,155 million and US\$14,769 million, respectively. ${ }^{18}$

The Pension Reserve Fund was designed to finance the central government's pension liabilities. In particular, the amounts that could be withdrawn from FRP were, until 2016, limited to the return it generated. After 2016, the maximum withdrawal will be equivalent to one third of the difference between pension expenditure in year $t$ and the equivalent expenditure in 2008. The fund's accumulation rule obeys the following formula:

$$
P_{t-1} Y_{t-1} \cdot \min \left\{0.5 \% ; \max \left(0.2 \% ; B E f_{t-1} / P_{t-1} Y_{t-1}\right)\right\}
$$

where $P_{t-1} Y_{t-1}$ and $B E f_{t-1}$ are the nominal GDP and actual balance of the last period, respectively. This means that the minimum contribution to the fund will be equivalent to $0.2 \%$ and the maximum equivalent to $0.5 \%$ of the previous year's GDP, depending on the balance actually recorded. Clearly, the existence of FRP, together with the interest it generates and its accumulation and disbursement rules, will be a central part of the future sustainability debate. Moreover, in the model, the periodic flows of contributions into this fund (which, as a stock, is an asset) are initially (up to 2016) treated as one more component of debt, since there is only an accumulation rule up to that date, although it may be treated as another source of funding after 2016.

\footnotetext{
16 If the net debt is negative, this expression will also be negative, which means interest income outweighing interest expenses.

17 On this point, see chapter VIII of DIPRES (2013), which applies similar formulas to project long-term tax revenues. See also the annexes in Crispi and Vega (2003) and Larraín and others (2011) for an explanation of these functional forms.

${ }^{18}$ For a review of the potential objectives of sovereign wealth funds and their different types, see IMF (2008) and Kunzel and others (2010). For the legal framework and operation of Chilean funds, see Contreras and others (2008).
} 
For its part, FEES is designed to act as a public expenditure stabilization fund, in the CAB policy framework. As expenditure is set according to the medium-term criteria of the Chilean fiscal rule, the actual budget outturn can be either positive or negative, depending on the phase of the cycle. FEES accumulates resources from the actual surplus in excess of 0.5\% of current-year GDP and serves as an additional deficit-financing tool apart from debt. As shown in Walker (2011), this fund has a long-term expected value of zero, and has no pre-established draw-down rules, such as those of FRP. In a deficit scenario, the government can choose between drawing on FEES funds, selling other assets or borrowing, either domestically or abroad. This is a discretionary decision of the authority and is usually associated with the macroeconomic conditions prevailing at the time. So, in a simplified model such as the one presented in the next section, the effect of including FEES as an asset element in net external debt is not relevant to this analysis. In other words, unlike FRP, FEES will not be modelled as a variable that is independent of net debt.

\section{(iii) Fiscal sustainability model in the context of the Chilean economy}

Following Talvi and Végh (2000), who emphasize the fiscal deficit more than the government's operating deficit, coverage will be restricted to total central government. Accordingly, the money creation variable, $\Delta M_{t}$, is dispensed with in the equations.

To determine the need for government financing, that is, whether new debt must be issued or existing debt can be amortized, the ex post calculation is performed as shown in the following flowchart:

\section{Diagram 1}

Model calculation flowchart

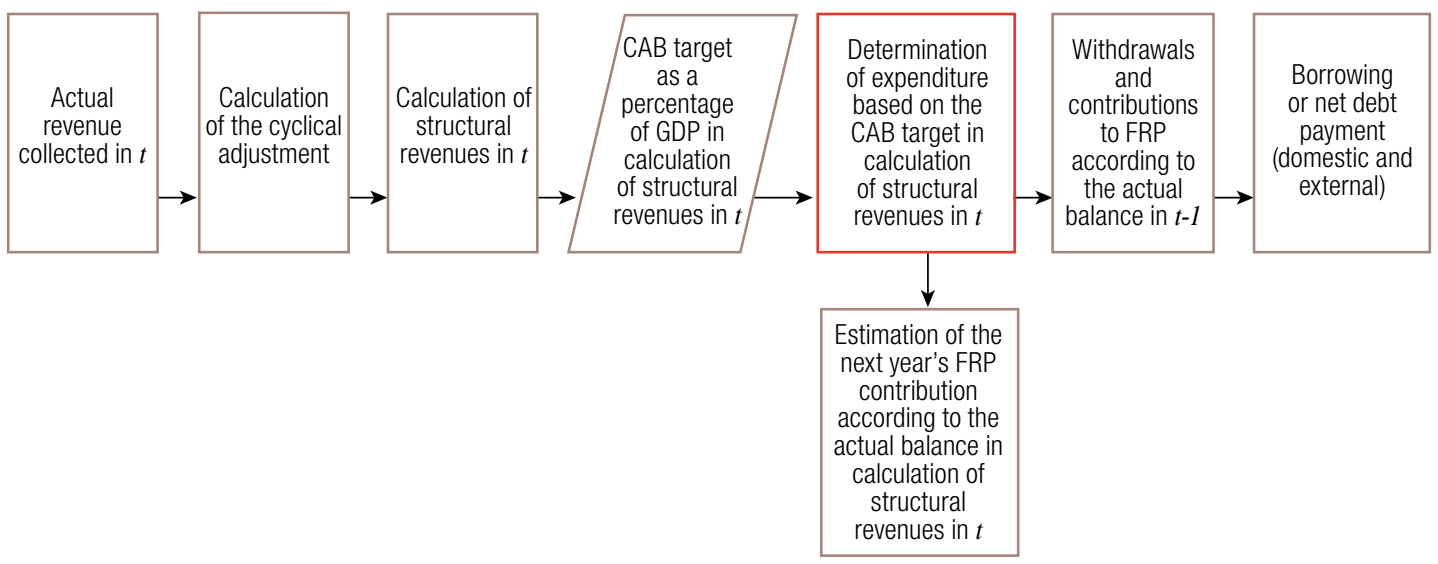

Source:Prepared by the authors.

As noted above, for the purposes of this analysis, central government revenues are divided into five categories: (1) non-mining tax revenue; (2) mining tax revenue; (3) transfers from CODELCO; (4) interest generated by FRP; and (5) other income. Of these, the first three are adjusted by the GDP or copperprice cycle, as appropriate. The cyclically adjusted revenues and target are then used to determine the government's expenditure, divided into three categories: (1) pension expenditure, (2) interest payments on the debt ${ }^{19}$ and (3) other expenses. According to the IMF Government Finance Statistics Manual (2001), these movements can be classified as "above-the-line" operations. In contrast, "below-the-line" (financing) operations include contributions and transfers to FRP and the issuance (or amortization) of

\footnotetext{
${ }^{19}$ As this involves net debt, interest expense may turn out to be negative, meaning that the interest generated by the assets outweighs the interest payable on the liabilities.
} 
debt. If the actual balance is positive, it serves as a source of funds; otherwise, it is added to the uses of the resources obtained through debt. ${ }^{20}$

Having specified the movements that occur "above the line" and "below the line", the equation to determine the stock and flow of the debt takes the following form: ${ }^{21}$

$$
\begin{gathered}
D_{t}=\left(1+i_{t}\right) \cdot D_{t-1}+\Delta F R P_{t}-B P_{t} \\
D_{t}=\left(1+i_{t}\right) \cdot D_{t-1}-B P_{t}^{\prime} \text { with } B P_{t}^{\prime}=B P_{t}-\Delta F R P_{t} \\
\Delta D_{t}=i_{t} D_{t-1}-B P_{t}^{\prime}=-B E f_{t}^{\prime}
\end{gathered}
$$

Where $\triangle F R P t$ is the variation in FRP in period $t$. It can then be seen that FRP is separate from the net debt component in dollars. Thus, the variation of the debt stock for a year as a percentage of GDP is given by the equation:

$$
\Delta d_{t}=\frac{r_{t}-g_{t}}{1+g_{t}} d_{t-1}+\frac{\Delta F R P_{t}}{P_{t} Y_{t}}-b p_{t}
$$

By performing a decomposition similar to equation (5), and given that the actual balance is equal to the CAB plus the cyclical adjustment of income, the debt movement as a percentage of GDP can be related to the $\mathrm{CAB}$ target as follows:

$$
\Delta d_{t}=-\frac{1-i_{t}}{1+\gamma_{t}} \gamma_{t} d_{t-1}+\frac{\Delta F R P_{t}}{P_{t} Y_{t}}-\left(\overline{b c a_{t}}-a c_{t}\right)
$$

where $\overline{b c a}_{t}$ is the CAB target as a percentage of GDP in year $t$, and $a c_{t}$ is the cyclical adjustment as a percentage of GDP in year $t$.

\section{(b) Projections of net debt to 2025}

To exemplify the functioning of the dynamic model developed in the foregoing sections, the Chilean central government's net debt path is simulated to 2025. The initial values of the main variables used in this exercise are consistent with the 2018 budget and the public-sector financial projection for 2019-2021, as reported by the Ministry of Finance in the Public Finance Report (DIPRES, 2017b).

The following describes the two alternative macroeconomic scenarios used in the analysis:22

(i) Trend scenario: the projected position in the 2018 budget and the public-sector financial projection for 2019-2021 and convergence to its trend values are considered as the initial position. Among other things, it is assumed that:

\footnotetext{
20 On the terms "Sources" and "Uses", see information provided in the footnote of Table I.17 of the report Evaluación de la Gestión Financiera 2017 (DIPRES, 2017c).

${ }^{21}$ Treasury liabilities recorded "below the line" include recognition bonds (Arenas and others, 2009). Following Vergara (2002) it was decided to only count recognition bonds already issued within the debt. Thus, the sustainability exercise remains valid, since non-payment of a recognition bond is the same as default on another type of bond, in terms of government solvency.

22 The macroeconomic variables used in the simulation of each scenario are presented in annex A3. For further analysis of the model used, see Bravo and others (2014).
} 
a. The gap between effective and trend GDP stays at zero as from 2022.

b. The price of copper would reach its reference value of US\$2.77 per pound by 2021 .

c. The structural balance target converges from $-1.2 \%$ of GDP in 2019 to a zero balance in 2024 , at an annual rate of $0.25 \%$ of GDP.

(ii) Adverse scenario: this alternative scenario considers very weak output growth in 2018 , of just $0.5 \%$ per year in real terms. The origin of this sharp slowdown is external, since it assumes a fall in the copper price to US\$1.5 per pound, with a depreciation of the peso and a rapid response in terms of interest rate cuts in both domestic and external economies.

The drag of the slowdown continues in 2019 and GDP starts to grow at rates above $2 \%$ in 2021 , converging towards an output gap of $1.8 \%$ in 2025.

In this scenario, no changes in the value of financial assets are simulated, so the impact on net indebtedness is only given by the simulated fiscal impulse. Lastly, this scenario simulates the results of different structural balance targets to face the slowdown and the effect on the net debt of each of these alternatives.

Lastly, given the pattern observed with social security expenditure in recent years, this exercise dispenses with FRP as a long-term income source for both scenarios, with pension expenditure growing at real rates of around $1.5 \%$. In other words, neither the interest that this fund generates nor any draw-downs that can be made as from 2016 are used.

\section{(i) Results}

Next, figure 3 shows the movement of net debt, both on its own and including FRP, in the trend scenario.

Figure 3

Trend scenario

A. Net debt, excluding the Pensions Reserve Fund (FRP)

(Percentages and millions of pesos)

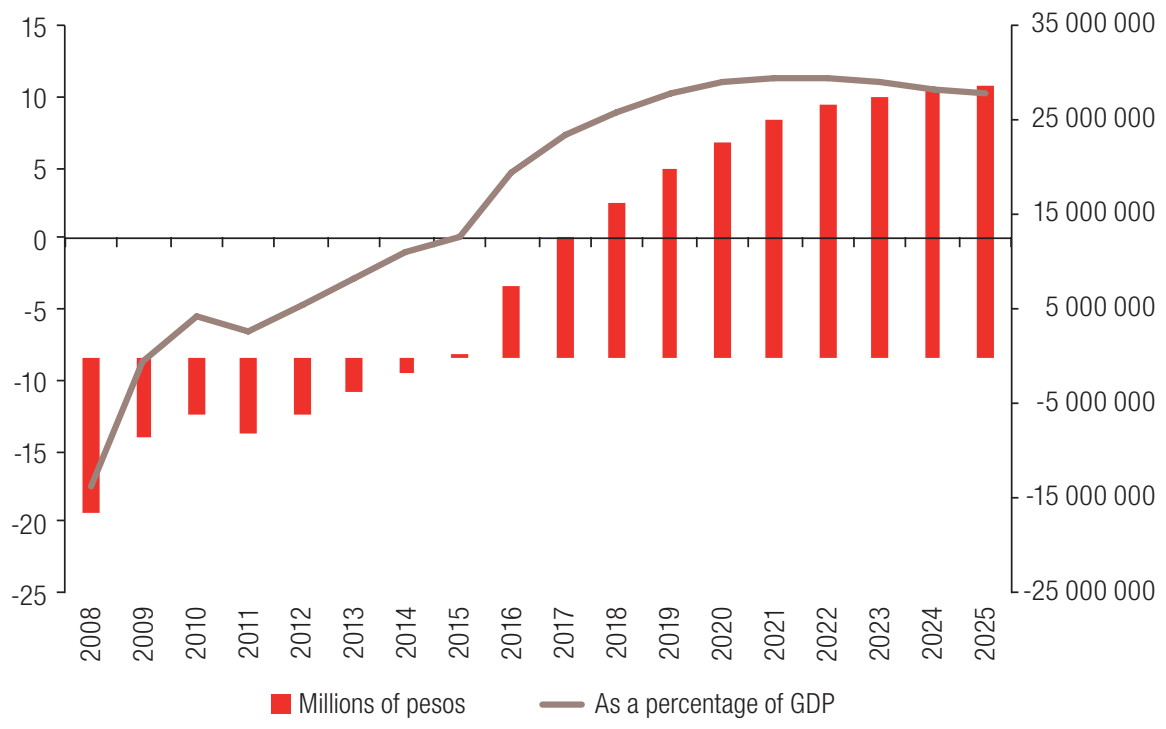


Figure 3 (concluded)

B. Net debt, including the Pensions Reserve Fund (FRP)

(Percentages and millions of pesos)

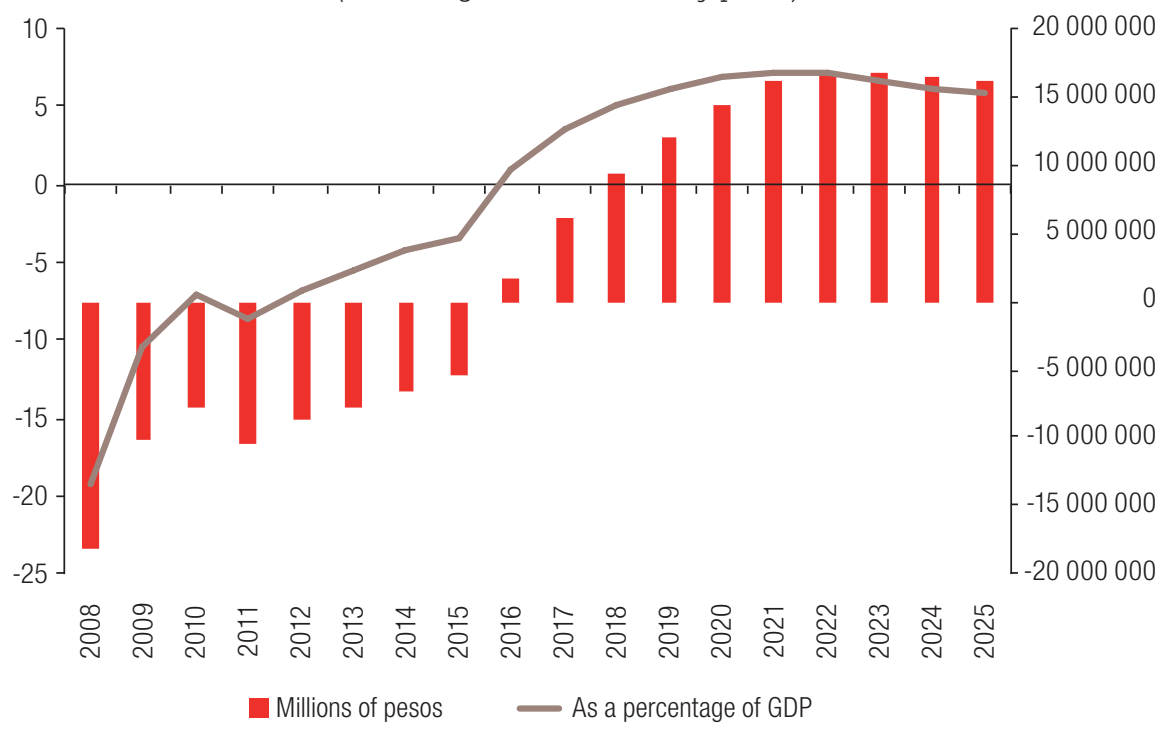

Source: Prepared by the authors.

As shown in figure 3, in the initial situation, central government net debt is close to equilibrium, in other words, in 2016 gross debt slightly exceeds the level of assets. This happens even when the net debt only includes FEES and other central government assets.

The projection envisages a gradual increase in net debt, which stabilizes as a percentage of GDP as from 2021. Given the assumed scenario, where the output gap closes in 2022, and with the differences between the actual and the cyclically adjusted balance explained by developments in the mining market, where the differences between current and trend prices are also narrowing, cyclically adjusted deficits also imply actual deficits, which means accumulating debt or selling assets (either from FEES or elsewhere). Figure 4, below, illustrates the effect on government spending of adhering to the cyclically adjusted balance target, in terms of real spending growth and its measurement as a percentage of GDP. There is a gradual reduction in spending as a percentage of GDP as from 2018, which is in line with a cyclically adjusted balance target that tends towards equilibrium. In this scenario, real variations in spending would be around $2.5 \%$ per year.

Table 2 applies the calculation of indicators II, VI and VII, which are shown in table 1,23 to the simulation.

The simulation shows a net debt tending towards equilibrium around 11\% of GDP if FRP is excluded and around 7\% of GDP if it is included. In both cases, the debt is expected to decrease slightly towards the end of the period. In contrast, repeated actual primary fiscal deficits are projected, which when corrected by the output cycle would produce structural primary surpluses close to $1 \%$ of GDP by the end of the projection period.

\footnotetext{
${ }^{23}$ Not all of the indicators presented in the foregoing sections are simulated, because the model as described does not make it possible to estimate all variables. For example, although the primary balance using the IMF and DIPRES methodology was presented earlier, this part of the document only considers the indicator constructed by DIPRES, since the model only separates interest income from FRP.
} 


\section{Figure 4}

Total expenditure: real growth and GDP in trend scenario (Percentages)

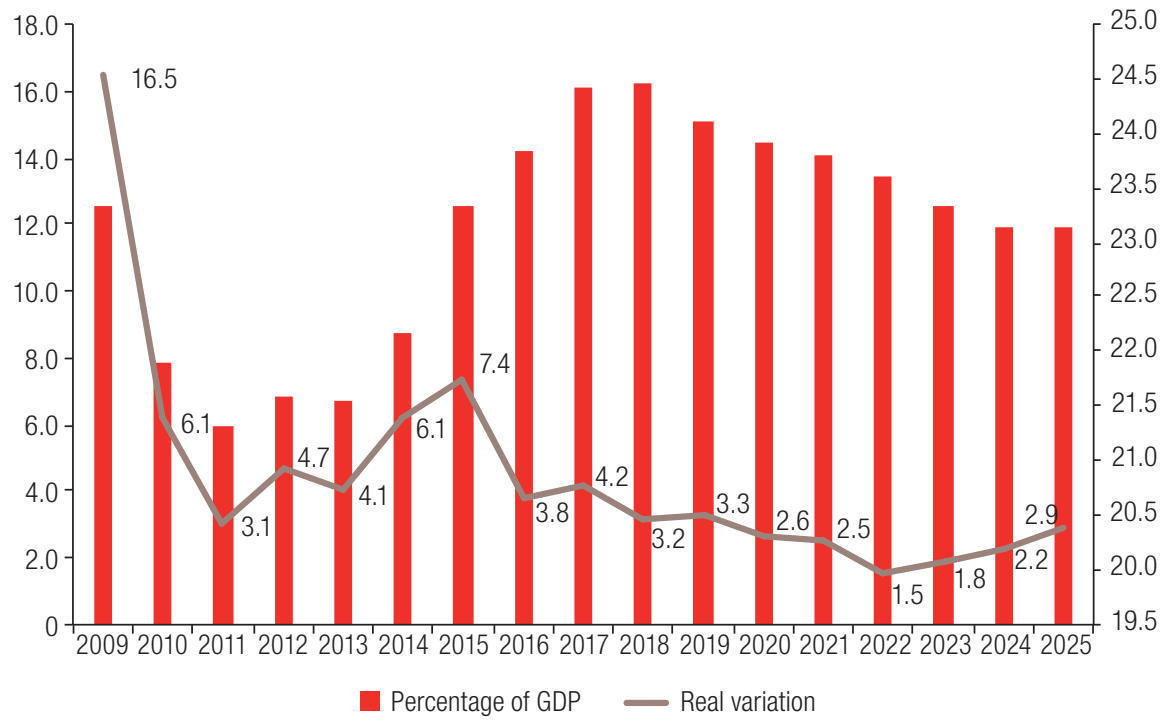

Source: Prepared by the authors, on the basis of information from the Budgetary Affairs Bureau and the Ministry of Finance.

Table 2

Static indicators of vulnerability and fiscal sustainability, projection 2018-2025a, trend scenario

(Percentages)

\begin{tabular}{lcccc}
\hline Year & $\begin{array}{c}\text { (II) Net debt (excluding } \\
\text { FRP) / GDP }\end{array}$ & $\begin{array}{c}\text { (II) Net debt (including } \\
\text { FRP) / GDP }\end{array}$ & $\begin{array}{c}\text { (VI) Primary balance } \\
\text { (DIPRES methodology) }\end{array}$ & $\begin{array}{c}\text { (VII) Structural } \\
\text { primary balance }\end{array}$ \\
\hline 2018 & 8.9 & 5.0 & -2.6 & -0.7 \\
\hline 2019 & 10.1 & 6.2 & -2.4 & -0.3 \\
\hline 2020 & 11.0 & 6.9 & -2.1 & 0.0 \\
\hline 2021 & 11.4 & 7.2 & -1.8 & 0.2 \\
\hline 2022 & 11.3 & 7.1 & -1.3 & 0.5 \\
\hline 2023 & 11.0 & 6.7 & -1.0 & 0.7 \\
\hline 2024 & 10.5 & 6.2 & -0.8 & 0.8 \\
\hline
\end{tabular}

Source: Prepared by the authors.

a The figures are consistent with the assumptions made when preparing the 2018 budget bill.

Figure 5 shows the results under the adverse scenario. ${ }^{24}$

${ }^{24}$ Corresponding to scenario (ii) of section (b) of this document. 
Figure 5

Adverse scenario

A. Net debt, including the Pensions Reserve Fund (FRP)

(Millions of pesos; as a percentage of GDP)

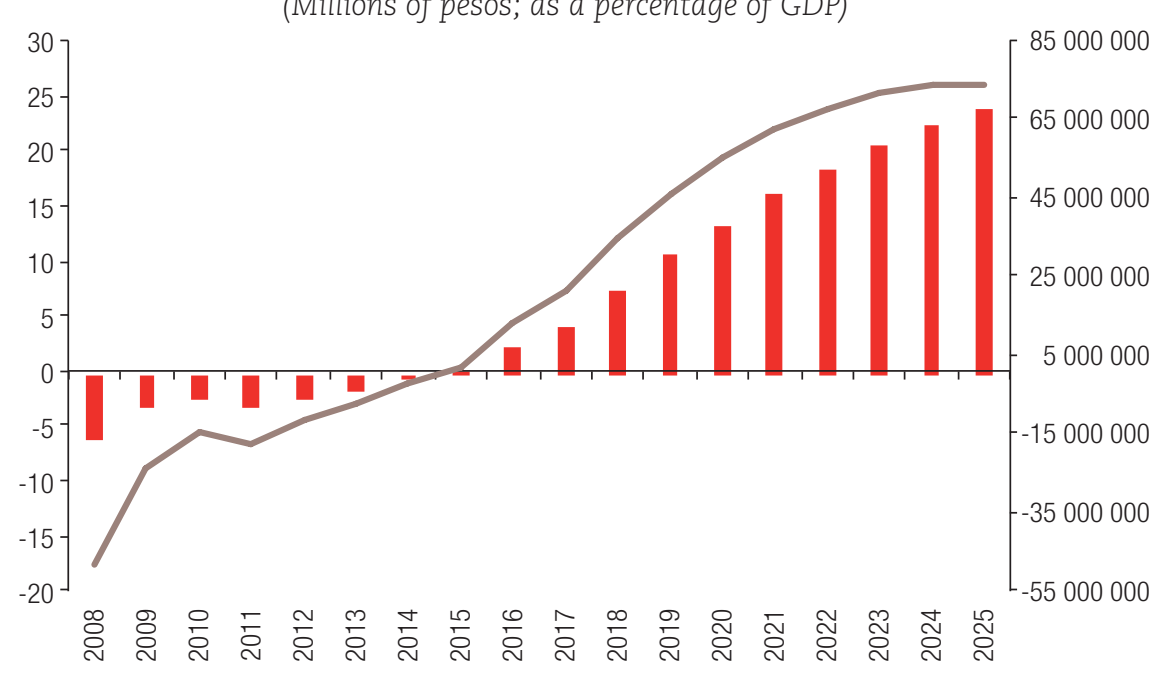

B. Net debt, including the Pensions Reserve Fund (FRP)

(Millions of pesos; as a percentage of GDP)

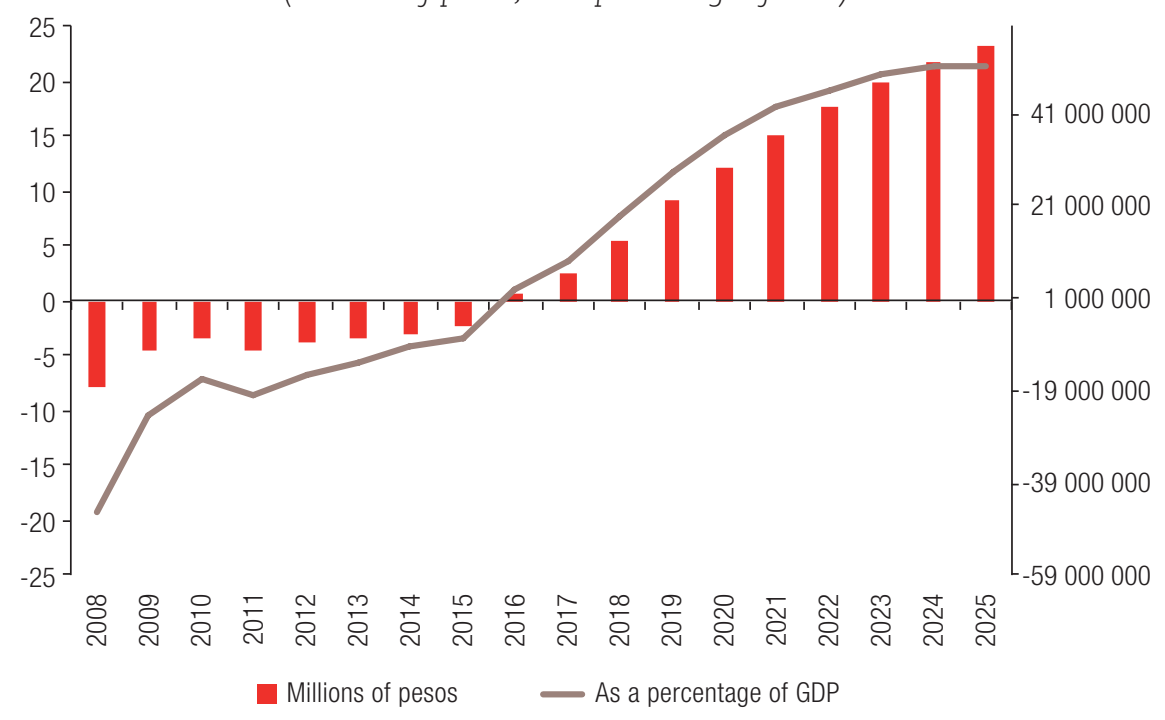

Source: Prepared by the authors.

As expected, an adverse activity shock fuels greater indebtedness (either by taking on more gross debt or by selling assets). A scenario in which activity slows sharply in 2018 could lead to net debt in excess of $20 \%$ of GDP in 2021 and trending up to reach $26 \%$ of GDP by the end of the projection period. This mainly reflects the fact that an adverse scenario, such as the one described, causes real GDP to dip below trend, thereby widening the output gap. Thus, the central government is forced to borrow or sell assets to meet its commitments and, at the same time, attain the CAB target. 
An important assumption is that the path of the target structural balance is the same as in the trend scenario, which means less room for spending growth. Figure 6 projects a gradual reduction in spending relative to GDP from 2019 onwards, which is in keeping with a cyclically adjusted balance target that tends towards equilibrium. In this scenario, variations in expenditure would be around $1.2 \%$ per year in real terms.

\section{Figure 6}

Total expenditure: real growth and GDP in trend scenario

(Percentages)

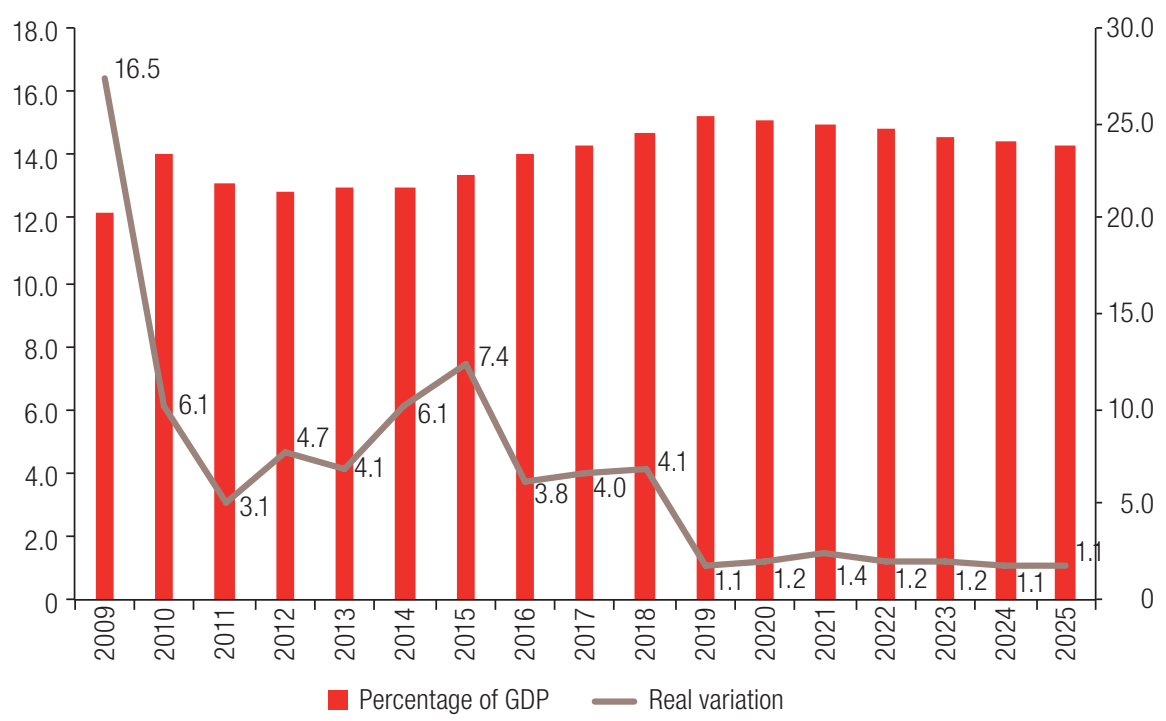

Source: Prepared by the authors, on the basis of information from the Budgetary Affairs Bureau and the Ministry of Finance.

As was done for the trend scenario, the trend of the simulated indicators to 2025 is also presented in this case. Table 3 shows a generalized deterioration of Chile's fiscal position, with primary deficits recorded in all years of the projection. In contrast, the structural primary deficits are smaller than the actual deficits, as a result of the cyclical adjustment of income, and they move into surplus as from 2024.

Table 3

Static indicators of vulnerability and fiscal sustainability, projection $2018-2025^{a}$, adverse scenario

(Percentages)

\begin{tabular}{lcccc}
\hline Year & $\begin{array}{c}\text { (II) Net debt } \\
\text { (excluding FRP) / GDP }\end{array}$ & $\begin{array}{c}\text { (II) Net debt } \\
\text { (including FRP) / GDP }\end{array}$ & $\begin{array}{c}\text { (VI) Primary balance } \\
\text { (DIPRES methodology) }\end{array}$ & $\begin{array}{c}\text { (VII) Structural } \\
\text { primary balance }\end{array}$ \\
\hline 2018 & 12.0 & 7.5 & -5.6 & -1.7 \\
\hline 2019 & 16.0 & 11.7 & -5.4 & -1.5 \\
\hline 2020 & 19.4 & 15.0 & -5.2 & -1.1 \\
\hline 2021 & 22.0 & 17.5 & -4.9 & -0.7 \\
\hline 2022 & 23.8 & 19.3 & -4.4 & -0.4 \\
\hline 2023 & 25.1 & 20.5 & -4.0 & -0.1 \\
\hline 2025 & 25.8 & 21.2 & -3.6 & 0.2 \\
\hline
\end{tabular}

Source: Prepared by the authors.

a The figures are consistent with the assumptions made when preparing the 2018 budget bill. 


\section{Final comments and man results}

Various studies, both national and international, have recognized the systematically orderly behaviour of Chile's public finances.

The use of fiscal sustainability indicators showed that Chile's fiscal situation improved steadily until 2009. Thereafter, the international financial crisis, followed by the earthquake and tsunami and growing pressures for increased fiscal spending eroded the country's fiscal position. In 2016 the central government ceased to be a net creditor and became a debtor. This fiscal position recalls 2004, when net debt represented 4\% of GDP; and it is consistent with the growth of gross debt, which in 2016 amounted to $21.3 \%$ of GDP, its highest level since 1994. This deterioration of the fiscal accounts was one of the reasons why the rating agencies downgraded Chile's rating for the first time in 25 years -from AA- obtained in 2012 to A+. Nonetheless, the figures can still be considered healthy in the international context.

The second part of this article puts forward a dynamic model to evaluate the long-term fiscal sustainability of the country. In particular, the study contributes to the literature by developing an ad hoc model for the Chilean economy; and it is the first to incorporate the dynamic of FRP, whose interest and accumulation and disbursement rules are crucial for projecting central government debt levels. Moreover, the calculation of the cyclically adjusted balance indicator is formalized in the empirical model, albeit in simplified form, taking account of the most recent changes introduced by the tax authority.

To exemplify the operation of the dynamic model, a macroeconomic trend scenario and a more adverse one in terms of activity were estimated. Table 4 summarizes the results of the simulation.

One conclusion of this exercise is that, considering a trend scenario based on the 2018 Budget Law, together with a fiscal policy consistent with the CAB rule and following the convergence goals proposed by the authority, Chile would attain net debt levels of around 10\% of GDP in 2025. This would entail total fiscal expenditure averaging 2.5\% through 2018-2025, together with an average economic growth rate of $3.2 \%$ and a copper price averaging US\$ 2.90 per pound in that period (see macroeconomic assumptions in annex A3). The analysis shows that, in this case, Chile would achieve a zero structural primary balance in 2020, a primary surplus in 2021 and a zero structural balance in 2024.

On the other hand, in an adverse scenario with average growth of $2.1 \%$ and an average copper price of US\$2.2 per pound in the period analysed, the country would reach levels of net indebtedness of around $26 \%$ of GDP in 2025. For this, total fiscal expenditure would need to average $1.6 \%$ per year in 2018-2025. This would mean attaining a structural primary surplus of $0.22 \%$ of GDP in 2024 , a primary balance of $-3.14 \%$ of GDP in 2025 and a structural balance of $-1.2 \%$ of GDP in 2025 . This adverse situation would leave the country with a fiscal situation very similar to that pertaining in the early 1990s, in conditions of vulnerability to new external crises and with high expenses associated with government debt service, diverting significant resources from social policy, It should be remembered, for example, that Chile paid more in interest than it spent on education and health between 1990 and 1993 (Arellano, 2017, p. 13) - a reality faced by many countries in the region that have been unable to properly manage their fiscal policy. That is why it is crucial for Chile to adhere to and reinforce its fiscal rule, since this is a very successful economic policy instrument that has afforded it a fiscal position that is an example even for countries of higher economic development levels. 
Table 4

Fiscal sustainability projection 2018-2025

(Percentages)

\begin{tabular}{lrrrrrrrr}
\hline Trend scenario & 2018 & 2019 & 2020 & 2021 & 2022 & 2023 & 2024 & 2025 \\
\hline Net debt (excluding FRP) (\% GDP) & 8.94 & 10.14 & 10.96 & 11.35 & 11.27 & 10.97 & 10.54 & 10.14 \\
\hline Real change in total spending & 3.22 & 3.26 & 2.59 & 2.50 & 1.54 & 1.84 & 2.24 & 2.92 \\
\hline Primary balance (DIPRES methodology) & -0.65 & -0.29 & -0.02 & 0.23 & 0.47 & 0.70 & 0.81 & 0.77 \\
\hline Structural primary balance & -0.70 & -0.30 & 0.00 & 0.20 & 0.50 & 0.70 & 0.80 & 0.80 \\
\hline Adverse scenario & 2018 & 2019 & 2020 & 2021 & 2022 & 2023 & 2024 & 2025 \\
\hline Net debt (excl. FRP) (\% GDP) & 11.98 & 16.03 & 19.40 & 21.97 & 23.77 & 25.05 & 25.80 & 26.06 \\
\hline Real change in total spending & 4.05 & 1.07 & 1.24 & 1.43 & 1.18 & 1.24 & 1.13 & 1.09 \\
\hline Primary balance (DIPRES methodology) & -5.60 & -5.42 & -5.20 & -4.86 & -4.38 & -3.98 & -3.57 & -3.14 \\
\hline Structural primary balance & -1.67 & -1.48 & -1.05 & -0.69 & -0.35 & -0.05 & 0.22 & 0.47 \\
\hline
\end{tabular}

Source: Prepared by the authors.

Lastly, it should be noted that the model developed in this study allows for multiple alternative simulations, with changes in the basic assumptions and the scenarios to be evaluated. One shortcoming is that the methodology presented is not set in an intertemporal standard macro model that would make it possible to separately analyse the stabilization virtues of this type of fiscal policy over time and its effects on growth, compared to alternative fiscal policies. Good starting points for such a study would be Kumhof and Laxton (2013) and Medina and Soto (2007), which do this kind of analysis on a partial basis, but without considering the improvements described in this article, namely incorporating the dynamics of FRP and calculating the CAB indicator according to the most recent changes introduced by the Chilean fiscal authority.

\section{Bibliography}

Alberola, E. and J. Montero (2007), "Debt sustainability and procyclical fiscal policies in Latin America", Working Papers, No. 0611, Madrid, Bank of Spain.

Arellano, J. P. (2017), Panorama fiscal: propuestas frente a una situación amenazante, Santiago, Corporation of Latin American Studies.

Arellano, S. and F. Larraín (1996), "Tipo de cambio real y gasto público: un modelo econométrico para Chile", Cuadernos de Economía, year 33, No. 98, Santiago, Institute of Economics, Catholic University of Chile.

Arenas, A. and others (2009), "Proyecciones fiscales del sistema de pensiones: bonos de reconocimiento y déficit operacional 2010-2050", Estudios de Finanzas Públicas, No. 14, Santiago, Budgetary Affairs Bureau (DIPRES).

Barnhill, T. and G. Kopits (2003), "Assessing fiscal sustainability under uncertainty", IMF Working Paper, No. 03/79, Washington, D.C., International Monetary Fund (IMF).

Blanchard, O. (1990), "Suggestions for a new set of fiscal indicators", OECD Economics Department Working Paper, No. 79, Paris, Organization for Economic Cooperation and Development (OECD).

Bohn, H. (2005), "The sustainability of fiscal policy in the United States", CESifo Working Paper, No. 1446 [online] http://www.cesifo.de/DocDL/cesifo1_wp1446.pdf.

(1998), "The behavior of U.S. public debt and deficits", The Quarterly Journal of Economics, vol. 113, No. 3, Oxford University Press.

Borensztein, E. and others (2010), "El manejo de los ingresos fiscales del cobre en Chile", Washington, D.C., Inter-American Development Bank (IDB).

Bravo, J. and others (2014), "Un modelo macroeconómico de proyección para Chile", Working Paper, No. 6, Santiago, Ministry of Finance.

Buiter, W. H. (1985), "A guide to public sector debt and deficits", Economic Policy, vol. 1, No. 1. 
Calvo, G. A., A. Izquierdo and E. Talvi (2003), "Sudden Stops, the Real Exchange Rate and Fiscal Sustainability: Argentina's Lessons", Inter-American Development Bank (IDB) [online] https://publications.iadb.org/ handle/11319/1909.

Caputo, R. and R. Valdés (2016), "A fiscal vaccine against the Dutch disease", Applied Economic Letters, vol. 23, No. 1, Taylor \& Francis.

Chalk, N. and R. Hemming (2000), "Assessing fiscal sustainability in theory and practice", IMF Working Paper, No. 00/81, Washington, D.C., International Monetary Fund (IMF).

Chan-Lau, J. and others (2010), "Chile: selected issues paper”, IMF Country Report, No. 10/299, Washington, D.C., International Monetary Fund (IMF).

Contreras, A. and others (2008), "Activos financieros del tesoro público chileno: resultados y desafíos", Estudios de Finanzas Públicas, No. 11, Santiago, Budgetary Affairs Bureau (DIPRES).

Corbo, V. and others (2011), Propuestas para perfeccionar la regla fiscal [online] http://www.dipres.gob. cl/594/articles-76544_doc_pdf.

Costa, R. and L. F. Lagos (2001), "Superavit estructural: ventajas y limitaciones", Informe Económico series, No. 120, Santiago, Libertad y Desarrollo.

Crispi, J. and A. Vega (2003), "Sostenibilidad y regla fiscal: análisis e indicadores para Chile", Estudios de Finanzas Públicas, No. 3, Santiago, Budgetary Affairs Bureau (DIPRES).

Dabán, T. (2011), "Strengthening Chile's rule-based fiscal framework", IMF Working Paper, No. WP/11/17, Washington, D.C., International Monetary Fund (IMF).

DIPRES (Budgetary Affairs Bureau) (2017a), Indicadores de balance cílcicamente ajustado. Metodología y resultados, 2016, Santiago.

(2017b), Informe de finanzas públicas del proyecto de ley de presupuestos del sector público, 2018, Santiago.

(2017c), Evaluación de la gestión financiera del sector público en 2016 y actualización de proyecciones para 2017, Santiago.

(2017d), "Estadísticas de las finanzas públicas, estado de operaciones del gobierno central” [online] http://www.dipres.gob.cl/594/w3-propertyvalue-15407.html.

(2013), "Evaluación de la gestión financiera del sector público en 2012 y actualización de proyecciones para 2013", Santiago [online] http://www.dipres.gob.cl/594/articles-104134_doc_pdf.pdf.

Ffrench-Davis, R. (2010), "Latin America: the structural fiscal balance in Chile, a move toward counter-cyclical macroeconomics", Journal of Globalization and Development, vol. 1, No. 1, De Gruyter.

Frankel, J. (2011), "A solution to fiscal procyclicality: the structural budget institutions pioneered by Chile", NBER Working Paper, No. 16945, Cambridge, Massachusetts, National Bureau of Economic Research (NBER) [online] www.nber.org/papers/w16945.pdf.

Gavin, M. and others (1996), "Managing fiscal policy in Latin America and the Caribbean: volatility, procyclicality, and limited creditworthiness", Working Paper, No. 326, Washington, D.C., Inter-American Development Bank (IDB).

Giorno, C. and others (1995), "Potential output, output gaps and structural budget balances", OECD Economic Studies, No. 24, Paris, Organization for Economic Cooperation and Development (OECD).

Hagemann, R. (1999), "The structural budget balance. The IMFs methodology", IMF Working Paper, No. 99/95, Washington, D.C., International Monetary Fund (IMF).

Hamilton, J. D. and M. A. Flavin (1986), "On the limitations of government borrowing: a framework for empirical testing", American Economic Review, vol. 76, No. 4, Nashville, Tennessee, American Economic Association.

IDB (Inter-American Development Bank) (2008), All That Glitters May Not Be Gold: Assessing Latin America's Recent Macroeconomic Performance, Washington, D.C., Research Department [online] http://idbdocs. iadb.org/wsdocs/getdocument.aspx?docnum=2246723.

Ilzetzki, E. and C. A. Végh (2008), "Procyclical fiscal policy in developing countries: truth or fiction?", NBER Working Paper, No. 14191, Cambridge, Massachusetts, National Bureau of Economic Research (NBER).

IMF (International Monetary Fund) (2010), "Staff guidance note on the application of the joint bank-fund debt sustainability framework for low-income countries", Policy Papers, Washington, D.C. (2008), "Sovereign wealth funds - A work program", Policy Papers, Washington, D.C. (2003), "Sustainability Assessments - Review of Application and Methodological Refinements" [online] http://www.imf.org/external/np/pdr/sustain/2003/061003.pdf. (2002), "Assessing Sustainability" [online] http://www.imf.org/external/np/pdr/sus/2002/eng/052802.pdf. (2001), Global Finance Statistics Manual, 2001 [online] https://www.imf.org/external/pubs/ft/gfs/manual/ esl/pdf/all.pdf. 
Kumhof, M. and D. Laxton (2013), "Simple fiscal policy rules for small open economies", Journal of International Economics, vol. 91, No. 1, Amsterdam, Elsevier.

_(2009), "Chile's structural fiscal surplus rule: a model-based evaluation", IMF Working Paper, No. 09/88, Washington, D.C., International Monetary Fund (IMF).

Kunzel, P. and others (2010), "Investment objectives of sovereign wealth funds: a shifting paradigm", Economics of Sovereign Wealth Funds: Issues for Policymakers, U. S. Das, A. Mazarei and H. van der Hoorn (eds.), Washington, D.C., International Monetary Fund (IMF).

Larch, M. and A. Turrini (2009), "The cyclically-adjusted budget balance in EU fiscal policy making: a love at first sight turned into a mature relationship", Economic Papers, No. 374, Brussels, European Commission.

Larraín, F. and others (2011), "Una política fiscal de balance estructural de segunda generación para Chile", Estudios de Finanzas Públicas, No. 18, Santiago, Budgetary Affairs Bureau (DIPRES).

Larraín, F. and F. Parro (2006), "Chile menos volátil", Santiago, Institute of Economics, Catholic University of Chile [online] https://www.researchgate.net/publication/46547988_Chile_menos_volatil/fulltext/0e5f6fe 8f0c4c08778fc5f89/46547988_Chile_menos_volatil.pdf.

Le Fort, G. (2006), "Política fiscal con meta estructural en la experiencia chilena", paper presented at the Second Annual Meeting of Latin American and Caribbean Debt Management Specialists (LAC Debt Group).

Ley, E. (2010), "Fiscal (and External) Sustainability”, World Bank [online] http://siteresources.worldbank.org/ INTDEBTDEPT/Resources/468980-1207588563500/4864698-1207588597197/FSPrimer.pdf.

Marcel, M. (2010), "La regla de balance estructural en Chile: diez años, diez lecciones", Washington, D.C., Inter-American Development Bank (IDB), unpublished.

Medina, J. P. and C. Soto (2007), "Copper price, fiscal policy and business cycle in Chile", Working Paper, No. 458, Santiago, Central Bank of Chile.

Mendoza, E. G. and P. M. Oviedo (2009), "Public debt, fiscal solvency and macroeconomic uncertainty in Latin America. The cases of Brazil, Colombia, Costa Rica and Mexico", Economía Mexicana. Nueva Época, vol. 18, No. 2, Mexico City, Economic Research and Teaching Centre. (2006), Fiscal Policy and Macroeconomic Uncertainty in Developing Countries: The Tale of the Tormented Insurer, Cambridge, Massachusetts, National Bureau of Economic Research (NBER).

OECD (Organization for Economic Cooperation and Development) (2010), Economic Survey of Chile 2010, Paris.

Restrepo, J. E. and C. Soto (2006), "Regularidades empíricas de la economía chilena: 1986-2005”, Economía Chilena, vol. 9, No. 2, Santiago, Central Bank of Chile.

Rodríguez, J., C. Tokman and A. Vega (2006), "Política de balance estructural: resultados y desafíos tras seis años de aplicación en Chile", Estudios de Finanzas Públicas, No. 7, Santiago, Budgetary Affairs Bureau (DIPRES).

Schmidt-Hebbel, K. (2010), "Fiscal rules and institutions in the world and in Chile", Santiago, unpublished.

Talvi, E. and C. A. Végh (2000), "La sostenibilidad de la política fiscal: un marco básico", ¿Cómo armar el rompecabezas fiscal? Nuevos indicadores de sostenibilidad, E. Talvi and C. A. Végh (comps.), Washington, D.C., Inter-American Development Bank (IDB).

Tapia, H. (2015), "Fiscal rule in Chile: from 'automatic pilot' to 'navigation device'”, May, unpublished.

Ter-Minassian, T. (2010), "Preconditions for a successful introduction of structural balance-based rules in Latin America and the Caribbean: a framework paper", Washington, D.C., International Monetary Fund (IMF), unpublished.

Velasco, A. and others (2010), "El enfoque de balance estructural en la política fiscal en Chile: resultados, metodología y aplicación al período 2006-2009", Estudios de Finanzas Públicas, No. 15, Santiago, Budgetary Affairs Bureau (DIPRES).

Vergara, R. (2002), "Política y sostenibilidad fiscal en Chile", Estudios Públicos, No. 88, Santiago, Centre for Public Studies.

Walker, E. (2011), "Un asset allocation para el FEES”, Santiago, unpublished [online] http://www.hacienda. cl/english/sovereign-wealth-funds/relevant-studies/un-asset-allocation-para-el-fees.html. 


\section{Annex A1}

\section{Fiscal vulnerability and sustainability indicators}

Government debt (indicators I and II)

$$
D_{t}=\frac{\text { debt stock }}{G D P_{t}}
$$

Debt service indicator (III and IV)

$$
\begin{gathered}
S D_{t}=\frac{\text { Amortisations }_{t}+\text { Interest payment }_{t}}{\text { Current income }_{t}} \\
S D_{t}(\text { acid test })=\frac{\text { Amortisations }_{t}+\text { Interest payment }_{t}}{\text { Current income }_{t}-\text { Copper income }_{t}}
\end{gathered}
$$

Primary balance indicator

(a) Traditional IMF methodology (indicator V)

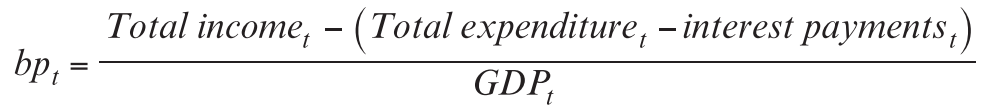

(b) DIPRES methodology (indicators VI and VII)

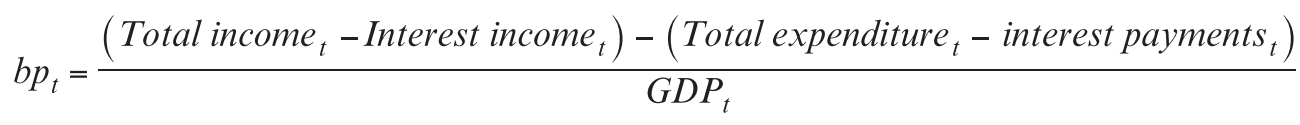




\section{Annex A2}

\section{Formal details of the fiscal sustainability model}

\section{Variation in net debt as a percentage of GDP}

Firstly, the Fisher equation is defined as follows:

$$
\left(1+r_{t}\right)=\left(1+i_{t}\right) /\left(1+\pi_{t}\right)
$$

Dividing net debt/nominal GDP $\left(\mathrm{P}^{*} \mathrm{Y}\right)$ of period $t$, gives:

$$
\begin{gathered}
\frac{D_{t}}{P_{t} Y_{t}}=\frac{\left(1+i_{t}\right) \cdot D_{t-1}}{P_{t} Y_{t}}-\frac{B P_{t}}{P_{t} Y_{t}}-\frac{\Delta M_{t}}{P_{t} Y_{t}} \\
d_{t}=\frac{\left(1+i_{t}\right)}{\left(1+g_{t}\right)\left(1+\pi_{t}\right)} d_{t-1}-b p_{t}-\Delta m_{t} \\
\Rightarrow d_{t}=\frac{\left(1+r_{t}\right)}{\left(1+g_{t}\right)} d_{t-1}-b p_{t}-\Delta m_{t}
\end{gathered}
$$

Subtracting the debt of the past period as a percentage of GDP on both sides of the equation, gives:

$$
\begin{gathered}
d_{t}-d_{t-1}=\Delta d_{t}=\frac{\left(1+r_{t}\right)}{\left(1+g_{t}\right)} d_{t-1}-d_{t-1}-b p_{t}-\Delta m_{t} \\
\Delta d_{t}=\frac{r_{t}-g_{t}}{1+g_{t}} d_{t-1}-b p_{t}-\Delta m_{t}
\end{gathered}
$$

\section{Decomposition: domestic and external debt, tradable and non-tradable GDP}

Government debt can be divided into domestic debt (superscript " $i$ ") and external debt (superscript " $e$ "). Each type of debt must pay interest according to the internal and external interest rate, respectively. Equation (A9) incorporates this decomposition into the law of debt movement.

$$
\begin{gathered}
D_{t}=D_{t}^{i}+e_{t} \cdot D_{t}^{e} \\
D_{t}=\left(1+i_{t}^{i}\right) D_{t-1}^{i}+e_{t}\left(1+i_{t}^{e}\right) D_{t-1}^{e}-B P_{t}-\Delta M_{t}
\end{gathered}
$$


where $e_{t}$ is the exchange rate (pesos per dollar) in period $t$. The following variables are also defined (Ley, 2010):

$$
\begin{gathered}
\alpha_{t}^{i}=\frac{D_{t}^{i}}{D_{t}} \\
\alpha_{t}^{e}=\frac{e_{t} \cdot D_{t}^{e}}{D_{t}} \\
\alpha_{t}^{i}+\alpha_{t}^{e}=1
\end{gathered}
$$

it is us possible to arrange equation (A9) to express it on the same terms as equation (13) presented in the body of the paper.

$$
\begin{gathered}
D_{t}=\left(1+i_{t}^{i}\right) D_{t-1}^{i}+\left(1+i_{t}^{e}\right) e_{t} D_{t-1}^{e}-B P_{t}-\Delta M_{t} \\
D_{t}=\left[\left(1+i_{t}^{i}\right) \alpha_{t-1}^{i}+\left(1+i_{t}^{e}\right)\left(1+\varepsilon_{t}\right) \alpha_{t-1}^{e}\right] D_{t-1}-B P_{t}-\Delta M_{t} \\
D_{t}=\left[1+i_{t}^{i} \alpha_{t-1}^{i}+\alpha_{t-1}^{e}\left(i_{t}^{e}+\varepsilon_{t}+i_{t}^{e} \varepsilon_{t}\right)\right] D_{t-1}-B P_{t}-\Delta M_{t} \\
D_{t}=\left(1+i_{t}\right) D_{t-1}-B P_{t}-\Delta M_{t}
\end{gathered}
$$

where $\varepsilon_{t}$ is the rate of depreciation of the exchange rate. The nominal interest in period $t$ is equal to:

$$
i_{t}=i_{t}^{i} \alpha_{t-1}^{i}+\alpha_{t-1}^{e}\left(i_{t}^{e}+\varepsilon_{t}+i_{t}^{e} \varepsilon_{t}\right)
$$

Just as it is possible to divide debt into its domestic and external components, GDP can be decomposed between tradable output (superscript " $i$ ") and non-tradable output (superscript "e"). ${ }^{25}$

$$
P_{t} Y_{t}=P_{t}^{i} Y_{t}^{i}+e_{t} P_{t}^{e} Y_{t}^{e}
$$

Defining the following variables:

$$
\begin{gathered}
w_{t}^{i}=\frac{P_{t}^{i} Y_{t}^{i}}{P_{t} Y_{t}} \\
w_{t}^{e}=\frac{e_{t} P_{t}^{e} Y_{t}^{e}}{P_{t} Y_{t}} \\
g_{t}=\frac{\Delta Y_{t}}{Y_{t-1}}
\end{gathered}
$$

and following an algebraic procedure similar to that applied for debt, nominal GDP in period $t$ can be written as a function of nominal GDP in the previous period:

$$
\begin{gathered}
P_{t} Y_{t}=\left(1+g_{t}\right)\left(1+w_{t-1}^{i} \pi_{t}^{i}+w_{t-1}^{e}\left(\pi_{t}^{e}+\varepsilon_{t}+\pi_{t}^{e} \varepsilon_{t}\right)\right) P_{t-1} Y_{t-1} \\
P_{t} Y_{t}=\left(1+g_{t}\right)\left(1+\pi_{t}\right) P_{t-1} Y_{t-1}
\end{gathered}
$$

where inflation in period $t$ is defined as:

$$
\pi_{t}=w_{t-1}^{i} \pi_{t}^{i}+w_{t-1}^{e}\left(\pi_{t}^{e}+\varepsilon_{t}+\pi_{t}^{e} \varepsilon_{t}\right)
$$

${ }^{25}$ See the separation proposed by Restrepo and Soto (2006) for calculating the tradable and non-tradable shares of GDP. 


\section{Compilation of the sustainability model for the Chilean economy}

The variation in net debt, separating FRP from government assets, is described as follows:

$$
\begin{gathered}
\Delta D_{t}=\Delta F R P_{t}-B E f_{t} \\
\Delta D_{t}=-B E f_{t}^{\prime} \\
\text { with } B E f_{t}^{\prime}=B E f_{t}-\Delta F R P_{t}
\end{gathered}
$$

FRP is separated from other government assets through its pre-established accumulation and disbursement rules. Contributions to FRP are expressed by the following formula:

$$
A F R P_{t}=P_{t-1} Y_{t-1} * \min \left\{0.5 \% ; \max \left\{0.2 \% ; B E f_{t-1} / P_{t-1} Y_{t-1}\right\}\right\}
$$

So the variation in FRP after 2016 is defined as:

$$
\begin{gathered}
F R P_{t}=F R P_{t-1}+A F R P_{t}-\frac{1}{3} *\left(\text { GPrev }_{t}-\text { GPrev }_{2008}\right) \\
F R P_{t}-F R P_{t-1}=A F R P_{t}-\frac{1}{3} *\left(\text { GPrev }_{t}-\text { GPrev }_{2008}\right) \\
\Delta F R P_{t}=A F R P_{t}-\frac{1}{3} *\left(\text { GPrev }_{t}-\text { GPrev }_{2008}\right)
\end{gathered}
$$

In view of the above, debt as a percentage of GDP is defined as:

$$
\begin{gathered}
\frac{D_{t}}{P_{t} Y_{t}}=\frac{\left(1+i_{t}\right) * D_{t-1}}{P_{t} Y_{t}}-\frac{B P_{t}^{\prime}}{P_{t} Y_{t}} \\
d_{t}=\frac{\left(1+i_{t}\right)}{\left(1+g_{t}\right)\left(1+\pi_{t}\right)} d_{t-1}-b p_{t}^{\prime} \\
d_{t}=\frac{\left(1+r_{t}\right)}{\left(1+g_{t}\right)} d_{t-1}-b p_{t}^{\prime}
\end{gathered}
$$

and the variation in the debt as a percentage of GDP is given by:

$$
\Delta d_{t}=\frac{r_{t} g_{t}}{1+g_{t}} d_{t-1}-b p_{t}^{\prime}
$$

Following the decomposition of Ley (2010), the following interest and inflation rates are defined:

$$
\begin{gathered}
\hat{i}_{t}=\propto_{t-1}^{i} i_{t}^{i}+\propto_{t-1}^{e} i_{t}^{e} \\
\hat{\pi}_{t}=\omega_{t-1}^{i} \pi_{t}^{i}+\omega_{t-1}^{e} \pi_{t}^{e}
\end{gathered}
$$

So the nominal interest rate and inflation are described as follows:

$$
\begin{aligned}
i_{t} & =\hat{i}_{t}+\varepsilon_{t} \propto{ }_{t-1}^{e}\left(1+i_{t}^{e}\right) \\
\pi_{t} & =\hat{\pi}_{t}+\varepsilon_{t} w_{t-1}^{e}\left(1+\pi_{t}^{e}\right)
\end{aligned}
$$


Substituting in equations (A10) y (A11) gives:

$$
\begin{gathered}
d_{t}=\frac{\left(1+\hat{i}_{t}+\varepsilon_{t} \propto_{t-1}^{e}\left(1+i_{t}^{e}\right)\right)}{\left(1+g_{t}\right)\left(1+\hat{\pi}_{t}+\varepsilon_{t} w_{t-1}^{e}\left(1+\pi_{t}^{e}\right)\right)} d_{t-1}-b p_{t}^{\prime} \\
\Delta d_{t}=\left(\frac{\left(1+\hat{i}_{t}+\varepsilon_{t} \propto_{t-1}^{e}\left(1+i_{t}^{e}\right)\right)}{\left(1+g_{t}\right)\left(1+\hat{\pi}_{t}+\varepsilon_{t} w_{t-1}^{e}\left(1+\pi_{t}^{e}\right)\right)}-1\right) d_{t-1}-b p_{t}^{\prime} \\
\Delta d_{t}=\left(\begin{array}{c}
\frac{\left(1+\hat{i}_{t}+\varepsilon_{t} \propto_{t-1}^{e}\left(1+i_{t}^{e}\right)\right)}{\left(1+\hat{\pi}_{t}+\varepsilon_{t} w_{t-1}^{e}\left(1+\pi_{t}^{e}\right)\right)} \\
\left(1+\hat{\pi}_{t}+\varepsilon_{t} w_{t-1}^{e}\left(1+\pi_{t}^{e}\right)\right) \\
\left(1+\hat{i}_{t}-\hat{\pi}_{t}\right)+\varepsilon_{t}\left(\hat{i}_{t-1}^{e}\left(1+\varepsilon_{t} w_{t-1}^{e}\right)-w_{t-1}^{e}\left(1+\varepsilon_{t}^{e}\left(1+\pi_{t}^{e}\right)\right)\right. \\
\left(1+g_{t}\right) \\
\left(1+i_{t}^{e}\right) \\
\Delta d_{t}=\frac{r_{t}-g_{t}}{1+g_{t}} d_{t-1}-b p_{t}^{\prime}
\end{array}\right) g_{t-1}^{e}-b p_{t}^{\prime}
\end{gathered}
$$

which thus defines the real interest rate. In contrast, making the dynamic of the debt a function of the actual balance relative to GDP, gives:

$$
\begin{gathered}
\Delta d_{t}=\frac{r_{t}-g_{t}}{1+g_{t}} d_{t-1}-b p_{t}^{\prime} \\
\Delta d_{t}=\frac{i_{t}-\gamma_{t}}{1+\gamma_{t}} d_{t-1}-b p_{t}^{\prime} \\
\Delta d_{t}=\frac{i_{t}-\gamma_{t}}{1+\gamma_{t}} d_{t-1}-i_{t} d_{t-1}+i_{t} d_{t-1}-b p_{t}^{\prime} \\
\Delta d_{t}=\frac{i_{t}-\gamma_{t}}{1+\gamma_{t}} d_{t-1}-i_{t} d_{t-1}+i_{t} d_{t-1}+\frac{\Delta F R P_{t}}{P_{t} Y_{t}}-b p_{t} \\
\Delta d_{t}=\frac{1+i_{t}}{1+\gamma_{t}} \gamma_{t} d_{t-1}+\frac{\Delta F R P_{t}}{P_{t} Y_{t}}-b e f_{t}
\end{gathered}
$$

The actual balance as a percentage of GDP can also be expressed in terms of the CAB target:

$$
\begin{gathered}
b e f_{t}=\frac{I T_{t}}{P_{t} Y_{t}}-\frac{G T_{t}}{P_{t} Y_{t}} \\
\frac{G T_{t}}{P_{t} Y_{t}}=\frac{I T_{t}^{*}}{P_{t} Y_{t}}-\overline{b c a_{t}} \\
b e f_{t}=\frac{I T_{t}}{P_{t} Y_{t}}-\left(\frac{I T_{t}^{*}}{P_{t} Y_{t}}-\overline{b c a_{t}}\right) \\
\Rightarrow b e f_{t}=\overline{b c a_{t}}-a c_{t}
\end{gathered}
$$


Thus, substituting the actual balance term, it is possible to write the debt dynamics equation as a function of the structural balance target:

$$
\Delta d_{t}=-\frac{1+i_{t}}{1+\gamma_{t}} \gamma_{t} d_{t-1}+\frac{\Delta F R P_{t}}{P_{t} Y_{t}}-\overline{b c a_{t}}-a c_{t}
$$

where $a c_{t}$, the cyclical adjustment as a percentage of GDP, is calculated as follows:

$$
\begin{gathered}
a c_{t}=\frac{I T N M_{t}}{P_{t} Y_{t}} \cdot\left(1-\left(\frac{Y_{t}^{*}}{Y_{t}}\right)^{n}\right) \\
+\frac{\left(V C_{t} \cdot\left(P_{t}^{C}-P_{t}^{*}\right)+V M_{t} \cdot\left(P M_{t}-P M_{t}^{*}\right)\right) \cdot e_{t} \cdot 2.204,62}{P_{t} Y_{t}} \\
+\frac{\left(P_{t}^{B M L}-P_{t}^{*}\right) \cdot \tilde{\tau}_{t} \cdot Q_{t} \cdot e_{t} \cdot 2.204,62}{P_{t} Y_{t}}
\end{gathered}
$$




\section{Annex A3}

\section{Simulated macroeconomic scenarios}

Both scenarios are based on what was published in the October 2018 Public Finance Report. Therefore, although in that report there were projections of figures whose actual value to date is already known, the fact that the information is in the public domain makes it easier to repeat the exercise.

Table A3.1

Trend scenario

(Percentages)

\begin{tabular}{|c|c|c|c|c|c|c|c|c|}
\hline & 2018 & 2019 & 2020 & 2021 & 2022 & 2023 & 2024 & 2025 \\
\hline \multicolumn{9}{|l|}{ GDP } \\
\hline Real variation rate (actual GDP) & 3.0 & 3.3 & 3.5 & 3.5 & 3.4 & 3.0 & 3.0 & 3.0 \\
\hline Real variation rate (trend GDP) & 2.6 & 2.7 & 2.8 & 2.9 & 3.0 & 3.0 & 3.0 & 3.0 \\
\hline Output gap & 2.2 & 1.7 & 1.0 & 0.4 & 0.0 & 0.0 & 0.0 & 0.0 \\
\hline \multicolumn{9}{|l|}{$\mathrm{CPI}$} \\
\hline Variation (ave./ave.) & 2.6 & 3.0 & 3.0 & 3.0 & 3.0 & 3.0 & 3.0 & 3.0 \\
\hline \multicolumn{9}{|l|}{ Peso / dollar exchange rate } \\
\hline Nominal value & 650 & 650 & 650 & 650 & 650 & 650 & 650 & 650 \\
\hline \multicolumn{9}{|l|}{ Price of copper in US\$ per pound } \\
\hline Nominal valu-London Metal Exchange & 2.9 & 2.8 & 2.8 & 2.8 & 2.9 & 2.9 & 2.9 & 2.9 \\
\hline Reference price & 2.8 & 2.8 & 2.8 & 2.8 & 2.8 & 2.8 & 2.8 & 2.8 \\
\hline \multicolumn{9}{|l|}{ Tax variables } \\
\hline Structural balance target (\% GDP) & -1.4 & -1.2 & -0.9 & -0.7 & -0.4 & -0.2 & 0.0 & 0.0 \\
\hline
\end{tabular}

Table A3.2

Adverse scenario

(Percentages)

\begin{tabular}{|c|c|c|c|c|c|c|c|c|}
\hline & 2018 & 2019 & 2020 & 2021 & 2022 & 2023 & 2024 & 2025 \\
\hline \multicolumn{9}{|l|}{ GDP } \\
\hline Real variation rate (actual GDP) & 0.5 & 1.5 & 2.0 & 2.5 & 2.8 & 2.5 & 2.5 & 2.5 \\
\hline Real variation rate (trend GDP) & 2.0 & 2.0 & 2.0 & 2.0 & 2.0 & 2.0 & 2.0 & 2.0 \\
\hline Output gap & 4.0 & 4.6 & 4.6 & 4.1 & 3.3 & 2.8 & 2.3 & 1.8 \\
\hline \multicolumn{9}{|l|}{$\mathrm{CPI}$} \\
\hline Variation (ave./ave.) & 0.04 & 0.02 & 0.025 & 0.03 & 0.03 & 0.03 & 0.03 & 0.03 \\
\hline \multicolumn{9}{|l|}{ Peso / dollar exchange rate } \\
\hline Nominal value & 750 & 700 & 695 & 690 & 685 & 680 & 675 & 670 \\
\hline \multicolumn{9}{|l|}{ Price of copper in US\$ per pound } \\
\hline Nominal value-London Metal Exchange & 1.5 & 2.0 & 2.1 & 2.2 & 2.3 & 2.4 & 2.5 & 2.6 \\
\hline Reference price & 2.3 & 2.3 & 2.3 & 2.3 & 2.3 & 2.3 & 2.3 & 2.3 \\
\hline \multicolumn{9}{|l|}{ Tax variables } \\
\hline Structural balance target (\% GDP) & -2.5 & -2.7 & -2.5 & -2.2 & -2.0 & -1.7 & -1.5 & -1.2 \\
\hline
\end{tabular}

Source: Prepared by the authors, on the basis of DIPRES, Informe de finanzas públicas del proyecto de ley de presupuestos del sector público, 2018, Santiago, 2017. 